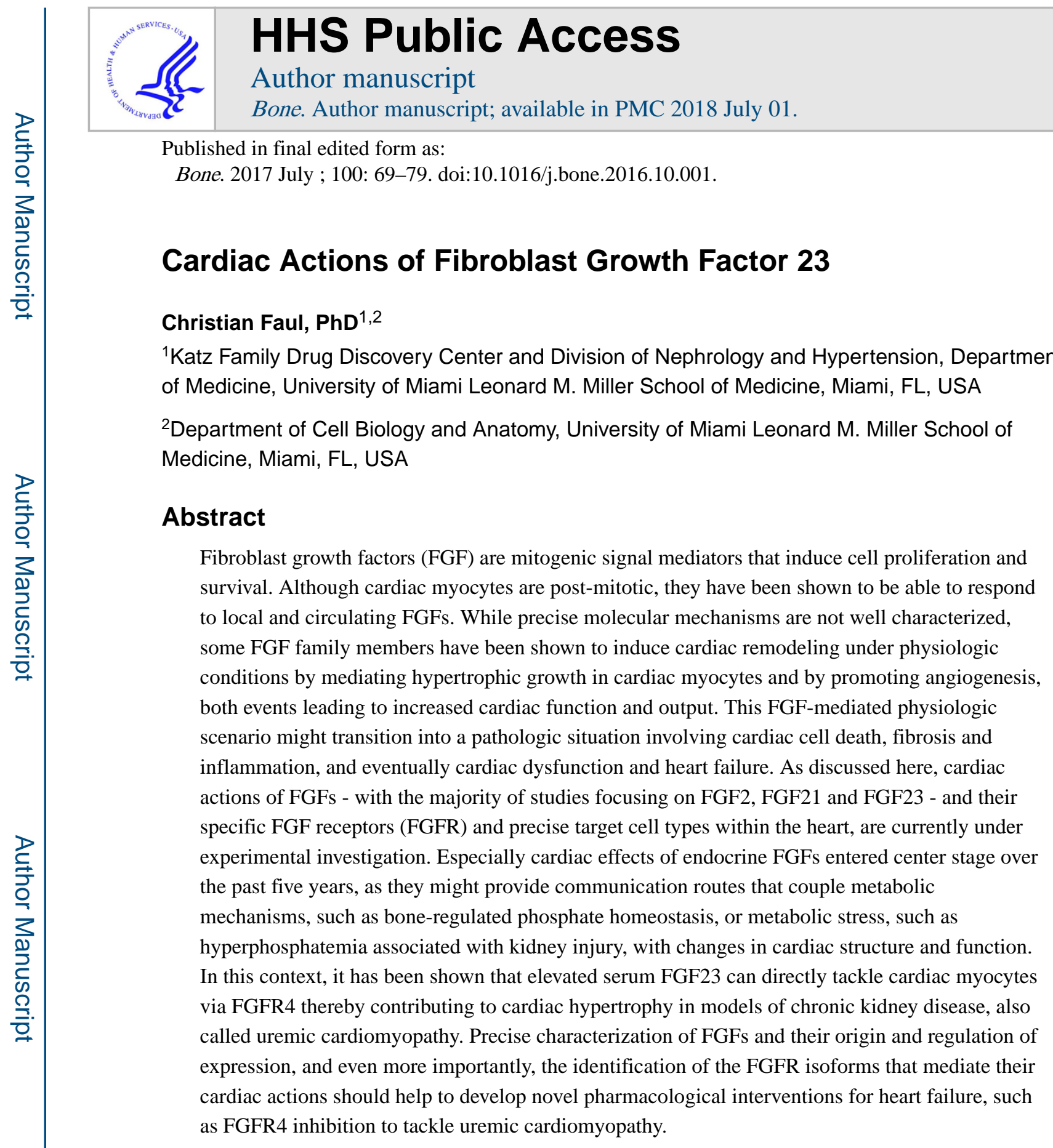

\title{
Keywords
}

Cardiac hypertrophy; Chronic kidney disease; Fibroblast growth factors; Receptor tyrosine kinases; Uremic cardiomyopathy

Correspondence should be addressed to: Christian Faul, PhD, 1580 NW 10th Avenue (R-762), Batchelor Children's Research Institute, Room 626, Miami, FL, USA 33136, Telephone: 305-243-3206, Fax 305-243-3209, cfaul@ med.miami.edu.

Publisher's Disclaimer: This is a PDF file of an unedited manuscript that has been accepted for publication. As a service to our customers we are providing this early version of the manuscript. The manuscript will undergo copyediting, typesetting, and review of the resulting proof before it is published in its final citable form. Please note that during the production process errors may be discovered which could affect the content, and all legal disclaimers that apply to the journal pertain. 


\section{The effects of growth factors on the heart}

Myocardial hypertrophy is an essential adaptive process through which the heart responds to various mechano-physical and metabolic stresses resulting in tissue protection and increased cardiac output (1). Dependent on the type of stress and the duration of stimulation, cardiac hypertrophy can become pathologic resulting in cardiac myocyte apoptosis and myocardial fibrosis and the development of heart failure $(2,3)$. The precise molecular events and cell types that contribute to the induction of the hypertrophic growth of cardiac myocytes and the activation of cardiac fibroblasts and to the transition from cellular protection to cell death are only poorly understood. Clearly, the development of pathologic cardiac hypertrophy is a complex process that involves a miscommunication between cardiac myocytes and fibroblasts, decreased capillary density, and actions of infiltrating monocytes $(4,5)$.

Several growth factors have been shown to be involved in the regulation of cardiac remodeling (6). Since shortly after birth cardiac myocytes become post-mitotic, one would assume that mitogenic growth factors do not directly target cardiac myoyctes, but rather affect the heart by inducing proliferation of cardiac fibroblasts (7). However since by contributing to cell survival and increased tissue mass and function, cellular hypertrophy in post-mitotic cells is similar to the proliferative state of dividing cells, it is possible that growth factors have direct pro-hypertrophic actions on cardiac myocytes and thereby regulate cardiac plasticity (1).

Among the many growth factors that employ receptor tyrosine kinases, only a few have been studied in regards to potential effects on cardiac myocytes. Insulin-like growth factor 1 (IGF-1) and its tyrosine kinase receptor, IGF-1R, have been shown to induce hypertrophy and promote survival of cardiac myocytes (8), which serves as a major mechanism for the induction of physiologic cardiac hypertrophy that elevates cardiac output in response to situations of increased demand, such as pregnancy or physical work-out $(9,10)$. Furthermore, neuregulin-1, a member of the epidermal growth factor (EGF) family and its tyrosine kinase receptor, ErbB2 (also known as HER-2 or c-neu), promote cardio-protection, including anti-apoptotic and pro-hypertrophic effects, and increase contractility of cardiac myocytes (11-14). This mechanism serves as an explanation for the clinical observation that cancer therapy against ErbB2 with trastuzumab (Herceptin) is often associated with the induction of cardiac dysfunction $(15,16)$. Finally, several members of the family of fibroblast growth factors (FGF) have also been shown to be involved in the regulation of cardiac remodeling (17), as discussed in detail here.

\section{An introduction to fibroblast growth factors}

The protein family of fibroblast growth factors (FGF) consists of 22 members (18) with varied functions dependent on their target tissue (19). The name of the family seems to be misleading since not all of its members can induce proliferation and survival in fibroblasts. Some seem to not even target fibroblasts at all, but promote growth of other cell types. Other members seem to lack any mitogenic activity, and rather induce cell migration or differentiation or regulate other cell type-specific functions, thereby lacking the defining feature of growth factors. Being a member of the FGF family is not defined by similarities in 
cellular actions, but is determined by the presence of an about 120 amino acid-long intrinsic protein domain that mediates FGF binding to a particular family of cell surface receptors, called fibroblast growth factor receptors (FGFR).

The biological effects of FGFs on target cells are mediated by their interaction with one of the four widely expressed FGFR isoforms (FGFR1-4) which belong to the superfamily of receptor tyrosine kinases (20). FGFRs consist of three external immunoglobulin (Ig)-like domains, a transmembrane domain and an intracellular tyrosine kinase domain. The four FGFRs are encoded by separate genes, and alternative splicing within the third Ig-like domain, which results in $\mathrm{b}$ and $\mathrm{c}$ variants, increases the variety within the FGFR family. The different FGFR isoforms and splice variants show different ligand binding specificities, and the presence of specific FGFRs determine if a cell can respond to a particular member of the FGF family.

FGFs can have paracrine, endocrine or intracrine functions (21). Intracrine FGFs (i.e. FGF11, FGF12, FGF13 and FGF14) are not released from the producing cells and act as FGFR-independent intracellular signal mediators. Their main function is the regulation of voltage-gated sodium channels in neurons $(22,23)$. To activate FGFR-mediated signaling in cells, paracrine-acting FGFs, such as FGF2 (also called basic FGF or bFGF), must bind to heparin or heparan sulfate proteoglycans (HPG) that function as cofactors promoting the FGF:FGFR interaction (24-26). In contrast, endocrine FGFs, i.e. FGF19, FGF21 and FGF23, have reduced affinity for HPG due to topological differences in their heparinbinding region $(27,28)$. Therefore, these FGFs are not captured by extracellular matrices and they can function as circulating hormones. However, this feature also reduces the capacity of HPG to promote FGF binding to FGFRs (29). Instead, endocrine FGFs require klotho, a single-pass transmembrane protein, as a co-receptor on target cells for efficient binding to FGFRs $(30,31)$. While FGFRs are widely expressed, the restricted distribution of klotho defines only a few selected tissues as physiologic targets for endocrine FGFs $(32,33)$.

The complex formation of FGF:FGFR:co-factor in a 2:2:2 stoichiometry leads to the activation of specific signal transduction pathways that converge in the nucleus to induce changes in gene expression (20). Belonging to the superfamily of receptor tyrosine kinases $(20,34,35)$, FGFR signaling is transduced by the cytoplasmic effectors, phospholipase $\mathrm{C} \gamma$ (PLC $\gamma$ ) and FGF receptor substrate $2 a$ (FRS2a) (20). Following ligand-induced autophosphorylation of FGFR, PLC $\gamma$ binds directly to one specific phosphorylated tyrosine residue within a consensus YLDL sequence in the FGFR cytoplasmic tail $(36,37)$. Subsequent tyrosine phosphorylation on $\mathrm{PLC} \gamma$ results in full PLC $\gamma$ activation by the receptor (38). Downstream signal transduction is mediated by PLC $\gamma$-catalyzed production of diacylglycerol and inositol 1,4,5-triphosphate $\left(\mathrm{IP}_{3}\right)$ that increases cytoplasmic $\mathrm{Ca}^{2+}$ levels and activates $\mathrm{Ca}^{2+}$-regulated signaling such as the calcineurin/nuclear factor of activated Tcells (NFAT) pathway (20). FGFR signaling can also be transduced via activation of FRS2a by FGFR-mediated tyrosine phosphorylation. In contrast to PLC $\gamma$, FRS2 $a$ is constitutively bound to FGFR independently of the receptor's activation state (39). FRS2a-mediated signaling results in activation of Ras/mitogen-activated protein kinase (MAPK) and phosphatidylinositol 3'-kinase (PI3K)/Akt signaling (20). 


\section{The role of fibroblast growth factor receptors in the heart}

Several FGFR isoforms appear to be present in the heart. A global FGFR expression screen by quantitative real-time PCR (qPCR) has shown that FGFR1 seems to be the main isoform in the mouse heart, with no or very low expression of FGFR2, FGFR3 and FGFR4 (40). A qPCR analysis of cardiac myocytes that were isolated from adult mice showed a similar outcome (41). In the human heart, FGFR1 expression has been detected by qPCR and immunoblotting (42), and cardiac myocyte localization has been determined by immunohistochemistry (43). FGFR1 functions as the main receptor for FGF2 and isolated cardiac myocytes that overexpress FGFR1 can bind FGF2 (44). Studies using radio-labeled FGF2 indicated the presence of FGFR1 in the rat heart (45) and in isolated cardiac myocytes $(46,47)$. Interestingly, a transgenic mouse line with inducible cardiac-specific overexpression of a constitutively active FGFR1 mutant form develops cardiac hypertrophy (48). In this model, acute transgene expression rapidly increases cardiac contractility while chronic expression causes cardiac hypertrophy and fibrosis. Although the underlying signaling pathways in cardiac myocytes are not understood, this study showed for the first time that cell autonomous activation of FGFR signaling is sufficient to induce cardiac hypertrophy. Since isolated cardiac myocytes that overexpress FGFR1 produce and secret higher levels of FGF2 (44), it is possible that FGF2/FGFR1 signaling is part of a paracrine feed-forward mechanism that regulates cardiac function and remodeling under physiologic conditions, and might contribute to pathologic cardiac hypertrophy when out of balance and over-activated.

Although FGFR2 plays an essential role in proper cardiac development (49-51), it seems to be absent from the adult heart $(40,43)$. This is further supported by a qPCR analysis detecting FGFR2 in neonatal but not in adult cardiac myocytes isolated from mice (41). FGFR3 seems to be absent form the adult heart (40, 43), and from neonatal as well as adult cardiac myocytes (41). Although some Northern blot and qPCR analyses indicate the absence of cardiac FGFR4 expression in mice and humans (40, 52, 53), other studies could detect FGFR4 mRNA in the adult human heart (42). Furthermore, FGFR4 can be detected by immunohistochemistry in the adult human heart (41-43), and by Western blot analysis in the mouse and human heart $(41,42,54)$. Although expression levels are low when compared to FGFR1, isolated cardiac myocytes from newborn as well as adult mice both express FGFR4 as revealed by qPCR (41). Furthermore, in the adult mouse heart FGFR4 is mainly expressed by myocytes, but not in non-myocytes including fibroblasts, as determined by flow cytometry analysis of isolated cardiac cell populations (41). Interestingly, a knockin mouse line that expresses a constitutively active FGFR4 mutant form at levels that are comparable to those of FGFR4 in wild-type mice (54), spontaneously develops cardiac hypertrophy (41). In these mice, cardiac calcineurin/NFAT signaling is elevated which might mediate the effect.

Overall it appears that in the adult heart FGFR1 is the predominant FGFR isoform that is expressed by different cell types, including high expression levels in cardiac myocytes. FGFR2 and FGFR3 seem to be absent while FGFR4 might be only present in cardiac myocytes and expressed at relatively low levels. Since activation of FGFR1 and FGFR4 per se appears to be sufficient to trigger pro-hypertrophic signaling and induce cardiac 
remodeling, it might be operative in different forms of pathologic cardiac hypertrophy and heart failure. Furthermore, since FGF/FGFR signaling seems to play an important role in cardiac remolding, it is not surprising that the FGFR expression pattern is altered in response to cardiac stress and injury. This has been shown in rats where after myocardial infarct FGFR1 levels increase in the area of injury (45). Since in this model delivery of an FGF2mutant with diminished affinity for FGFR1 is not cardio-protective (55), and administration of a pan-FGFR inhibitor prevents the cardio-protective effects of FGF2 (56), FGF2/FGFR1 signaling seems to play an important role in cardiac regeneration following infarction. Furthermore, in a Zebrafish model of cardiac regeneration following myocardial ablation, expression levels of FGFR2 and FGFR4 are increased (57). Finally, in cardiac hypertrophy associated with kidney injury (also called uremic cardiomyopathy and discussed in more detail below), cardiac FGFR4 and FGFR1 levels are significantly elevated in patients (42) and rat models (58), respectively. In this scenario, FGFR4 activation and subsequent PLC $\gamma /$ calcineurin/NFAT signaling seems to promote cardiac hypertrophy $(41,59)$.

FGFRs are potent drug targets, and based on mitogenic effects of FGF/FGFR signaling pharmacologic FGFR inhibitors are used in cancer therapy (35). However, since pan-FGFR inhibition is toxic in humans $(60,61)$ and induces cardiovascular dysfunction in rats $(62)$, the development of more targeted approaches to block the specific culprit FGFR isoform is necessary. To do so, it is inevitable to experimentally determine activation rather than expression of specific FGFR isoforms in the heart, since the receptor's activity state and expression level do not necessarily correlate with each other. This could be done by immunoprecipitation-immunoblot analysis of cardiac protein extracts to determine the degree of tyrosine-phosphorylation of specific FGFR isoforms. However, compared to qPCR expression analyses such protein-based assays are experimentally challenging and expensive. Cardio-protective effects of isoform-specific FGFR blockade have been shown for the first time in a rat model of uremic cardiomyopathy, where administration of an FGFR4-specific blocking antibody prevented the development of cardiac hypertrophy and fibrosis (41).

\section{The effects of paracrine fibroblast growth factors on the heart}

Among the paracrine-acting FGF family members, FGF2 seems to play an important role in the regulation of cardiac remodeling (63-65). Several studies have reported that FGF2 induces hypertrophic growth of cultured cardiac myocytes (66-70). Since FGF2 induces a switch in expression of $\beta$-myosin heavy chain from the adult to fetal isoform (66), it seems that FGF2-mediated hypertrophy is pathologic. However, since FGF2 treatment of cardiac myocytes increases intracellular calcium levels and contraction (71), it is likely that FGF2 can also induce transient physiologic hypertrophy. In addition, FGF2 has protective and antiapoptotic effects in cultured cardiac myocytes (72). As reported in other cell types, FGF2 activates MAPK signaling in cardiac myocytes $(69,73-76)$, which has been shown to contribute to cardiac hypertrophy in a variety of animal models (77). Furthermore, in cardiac myocytes and isolated hearts FGF2 induces calcium-mediated signal transduction, including activation of $\mathrm{PLC} \gamma, \mathrm{IP}_{3}$, calcineurin and protein kinase $\mathrm{C}(71,72,74,75,78-80)$, which are also major inducers of cardiac hypertrophy (3). 
Although FGF2 has clear hypertrophic effects in cardiac myocyte cultures, transgenic mice with global or cardiac-specific overexpression of $\operatorname{FGF} 2(75,76,81)$ and rats that received systemic infusions of recombinant FGF2 (82) do not develop cardiac hypertrophy, indicating that FGF2 per se cannot induce cardiac hypertrophy in vivo. Instead, FGF2 seems to modify cardiac remodeling in response to other stress or injury stimuli. Several stimuli that induce pathology cardiac hypertrophy have been shown to elevate FGF2 expression in cardiac myocytes, including angiotensin II (AngII) (69), aldosterone (83), as well as $\alpha 1$ - and $\beta$ adrenergic agonists $(84,85)$. Overexpression of FGF2 in transgenic mice exacerbates hypertrophy due to $\beta$-adrenergic stimulation $(76,86)$, while FGF2 knockout mice are protected (76). Furthermore, FGF2 knockout mice are protected from pathologic cardiac hypertrophy induced by pressure overload (87) or hypertension (69). These in vivo studies indicate that cardiac FGF2, although not a potent inducer of cardiac remodeling by itself, mediates the development and progression of pathologic cardiac hypertrophy in the presence of other stress stimuli.

As a potent inducer of fibroblasts proliferation and survival, FGF2 might also contribute to pathologic cardiac remodeling by promoting cardiac fibrosis. Indeed, it has been shown that compared to wild-type mice, FGF2 deficient mice develop less fibrosis when challenged by coronary ligation (88). Furthermore in response to AngII, cardiac fibroblasts release FGF2 that in an autocrine manner induces fibroblast activation and in a paracrine manner causes hypertrophic growth of cardiac myocytes (70). Since transgenic mice with FGF2 overexpression have more infiltrated leukocytes in the heart $(86,89)$, and in the hypertrophic heart FGF2 expression correlates with levels of inflammatory cytokines (83), FGF2 might contribute to cardiac injury by inducing local inflammation. Finally, FGF2 might harm the heart via systemic effects. Global FGF2 knockout mice are hypotensive $(90,91)$ indicating that FGF2 might elevate blood pressure and thereby contribute to cardiac remodeling.

In contrast, several other studies indicate that FGF2 does not promote pathologic cardiac remodeling but is rather cardio-protective. Mechanical activity can induces the release of FGF2 from cardiac myocytes evoking a paracrine hypertrophic response $(67,85)$, indicating that FGF2 might be part of a paracrine mechanism that increases cardiac function. One study reported that transgenic FGF2 mice are actually protected from pathologic cardiac hypertrophy following isoproterenol injections for continuous $\beta$-adrenergic activation (89). Furthermore, many studies in different animal models as well as ex vivo models for ischemia-reperfusion injury and cardiac infarct have shown that elevating FGF2 is cardioprotective and increases resistance to injury as well as the healing process $(56,75,81,92-$ 96). In this context, FGF2 might induce hypertrophy in the non-infarcted myocardium and actually prevents from cardiac fibrosis $(95,97,98)$. Since cardiac FGF2 expression is elevated following ischemia-reperfusion injury $(45,95), \mathrm{FGF} 2$ might be part of a paracrine mechanism that protects from ischemic heart damage. Interestingly, FGF2 seems to also promote the differentiation of cardiac precursor cells into functional cardiac myocytes in the adult heart thereby potentially contributing to cardiac repair (99). Besides directly targeting myocytes, beneficial cardiac effects of FGF2 might also involve FGF2's function as a potent stimulator of neovascularization. FGF2 transgenic mice show increased capillary density in the myocardium (75), and FGF2-mediated reduction in infarct size in animal models 
involves increased cardiac angiogenesis and improved coronary flow $(45,79,93-95,100$, 101).

Several, if not all cell types in the heart, including cardiac myocytes and endothelial cells, express FGF2 under normal conditions $(65,102-104)$. Surprisingly, global FGF2 knockout mice are viable and fertile and exhibit no baseline alterations in cardiac function and structure $(76,81,87,91)$. Therefore, FGF2 seems to be dispensable for proper development and regulation of the heart. Alternative, upregulation of other FGF members could compensate for the loss of FGF2 expression, but experimental evidence is missing. Instead cardiac FGF2 seems to come into action in the presence of other primary stimuli, and then contributes to protective or pathologic effects. If FGF2's action are beneficial or harmful might depend on the inducing stimulus as well as the precise levels and duration of FGF2 expression. Furthermore, the precise cell type(s) of FGF2 origin as well as the target cell type(s) for FGF2 actions within the heart have not been determined. Clearly, animal models with cell-type specific deletion of FGF2 as well as its receptor(s) are necessary to better understand the precise order and nature of cardiac events.

FGF1, also called acidic FGF or aFGF, and like FGF2 a prototypical paracrine FGF with mitogenic effects on fibroblasts, is also expressed and released by cardiac myocytes $(65,85$, 102, 103). Although FGF1 activates MAPK and PLC $\gamma$ signaling in cultured cardiac myocytes $(41,73)$, it seems that it cannot induce hypertrophic myocyte growth in vitro (66). It is not known if FGF1 has hypertrophic effects in vivo and/or affects cardiac remodeling that is induced by other stimuli. As shown for FGF2, cardiac expression levels of FGF1 are also elevated in animal models of myocardial infarct that is associated with angiogenesis and repair $(45,105)$. Experimental elevation of cardiac FGF1 in animal models for myocardial infarct seems to reduced infarct size, suggesting cardio-protective actions of FGF1 (45), but precise underlying mechanisms are not understood.

Similarly, myocardial elevation of FGF5 expression induces cardiac hypertrophy and improves cardiac function in an animal with hibernating myocardium (106). Interestingly, hypertrophic growth of cardiac myocytes rather than angiogenesis appears to be responsible for beneficial effects. FGF9 seems to be another paracrine FGF family member that promotes myocardial vascularization and remodeling. Conditional overexpression of FGF9 in adult mice induces cardiac hypertrophy, and following infarct transgenic mice show cardio-protection including increased microvessel density, reduced fibrosis and increased survival (107). Interestingly, FGF9 per se cannot directly induce hypertrophy in isolated cardiac myocytes, but rather promotes hypertrophic myocyte growth by target endothelial cells. Since the normal and infarct heart expresses FGF9 only at low levels (108), it is thought that FGF9 release by infiltrating bone marrow cells mediates adaptive cardiac hypertrophy following myocardial infarct (107). Finally, FGF16 seems to be predominantly expressed in the adult heart (109) where it has cardio-protective effects (110). Similar to FGF2 knockout mice, AngII-induced cardiac hypertrophy and fibrosis is increased in mice lacking FGF16 (111).

Besides its essential role in proper cardiac development (112), the family of FGFs seems to have important regulatory functions in the adult heart. However, if FGFs regulate cardiac 
remodeling under physiologic conditions or modulate cardiac remodeling in the context of cardiac stress contributing or protecting from injury is not entirely clear. Underlying molecular mechanisms of FGF actions are not well understood. Precise origin of FGF production and release within the heart or from infiltrating cells as well as the precise target cell types for FGFs are not well described. If FGFs can directly induce hypertrophic growth of cardiac myocytes and/or can target fibroblast and promote fibrosis or alter the communication between fibroblasts and myocytes is unclear. Since many FGFs promote angiogenesis some of the family's cardiac effects might be caused by increased vessel density.

\section{The role of endocrine fibroblast growth factors as metabolic regulators}

The three endocrine FGFs, termed FGF19, FGF21 and FGF23, have important and distinct metabolic functions that are mediated by FGFRs as well as klotho co-receptors on their specific target organs $(113,114)$. a-klotho serves as the co-receptor for FGF23 (32), and $\beta$ klotho as co-receptor for FGF19 and FGF21 (115). Whereas FGFRs are broadly expressed across tissues, klotho co-receptors have a more restricted expression pattern thereby conferring tissue-specificity to the action of endocrine FGFs resulting in specific physiologic effects (116).

FGF19 is a hormone that regulates diverse aspects of the postprandial response (117). Expressed in enterocytes of the small intestine, FGF19 acts on the liver to repress bile acid synthesis and gluconeogenesis. FGF19 directly targets hepatocytes via FGFR4 and $\beta$-klotho resulting in the activation of MAPK signaling $(116,118-120)$. In addition to its beneficial effects on liver metabolism, FGF19 also stimulates hepatocyte proliferation, and chronic exposure of mice to FGF19 results in hepatocellular carcinomas $(121,122)$.

FGF21 is an adipokine that is mainly produced by hepatocytes (123). FGF21 binds $\beta$-klotho in complex with FGFR1, 2 and 3, but not with FGFR4, and thereby activates the Ras/MAPK signaling cascade $(116,124,125)$. Knockout studies in mice suggest that the FGFR1 isoform is particularly important for the in vivo actions of FGF21 $(126,127)$. Furthermore, studies with global $\beta$-klotho knockout mice showed that $\beta$-klotho is essential for the physiological functions of FGF21 $(124,125)$. FGFR1/ $\beta$-klotho in adipocytes and in neurons of the hypothalamus serves as the main target receptor for FGF21 (117).

FGF21 regulates important aspects of metabolism and energy homeostasis in response to nutritional stress by primarily acting on white and brown adipose tissue (117). Hepatic and serum FGF21 levels rise in response to starvation that results in an increase in insulin sensitivity and increased glucose uptake and fatty acid storage in adipocytes (117). Furthermore, FGF21 induces browning of white adipose tissue and thermogenesis (128). FGF21 has also dramatic effects on liver metabolism including the induction of fatty acid oxidation, ketogenesis and gluconeogenesis, as well as the suppression of lipopgenesis (129-131). However, since the liver only expresses FGFR4 $(132,133)$, whereas FGFR1 in concert with $\beta$-klotho function as the FGF21 receptor (116), hepatic effects of FGF21 appear to be indirect (117). Overall, FGF21 has beneficial metabolic actions. FGF21 lowers circulating and hepatic triglyceride and cholesterol concentrations, reduces blood glucose 
levels, causes weight loss and increases life span (117). Serum FGF21 levels are elevated in diabetic animal models and in patients with type-2 diabetes (134-139) as well as in obese rodents and humans $(137,140,141)$. Since FGF21 has beneficial metabolic effects by increasing insulin sensitivity and reducing serum glucose levels (117), FGF21 elevations in these scenarios most likely have compensatory effects. However, diabetes and obesity may reflect an induced state of FGF21 resistance where expression levels of $\beta$-klotho are reduced and the organism cannot longer respond to circulating FGF21 (142).

FGF23 is a bone-secreted hormone that lowers serum phosphate levels (143). In the kidney and parathyroids, the classic target organs for FGF23, the hormone binds FGFR/a-klotho co-receptor complexes $(30,32)$. Knockout studies have shown that FGFR1 is the main FGFR isoform that mediates physiologic effects of FGF23 (144, 145), but FGFR3 and FGFR4 seem to be also involved (146-148). As shown in mice lacking a-klotho, renal aklotho is required for FGF23's phosphaturic actions $(149,150)$.

FGF23 is primarily secreted from osteocytes in response to dietary phosphorus loading or high serum phosphate and vitamin D levels (151). FGF23's endocrine effects on phosphate metabolism include: (i) Decreasing the activity of sodium-phosphate cotransporters, NaPi-2a and $\mathrm{NaPi}-2 \mathrm{c}$, in the kidney proximal tubule leading to increased urinary phosphate excretion (152). (ii) Down-regulating the expression of 1a-hydroxylase, the enzyme responsible for synthesizing 1,25-dihydroxyvitamin $\mathrm{D}_{3}$ (calcitriol) from its precursor and concurrently upregulating the expression of 24-hydroxylase, the enzyme that inactivates calcitriol, in the proximal tubule (152). (iii) Inhibiting the secretion of parathyroid hormone (PTH) from the parathyroid gland (33). Taken together, FGF23 induces a negative phosphate balance by functioning as a phosphaturic hormone and inhibitor of vitamin $\mathrm{D}$, which leads to decreased absorption of phosphorus in the gut (153-155). As an overall physiological effect, FGF23 reduces phosphate absorption from the intestine and increases phosphate excretion by the kidney. These FGF23-mediated processes also help to prevent overt hyperphosphatemia early in the course of diminished renal function.

\section{The effects of endocrine fibroblast growth factors on the heart}

By targeting the heart, endocrine FGFs could couple metabolic regulation with cardiac remodeling and thereby provide a signaling mechanism that induces adaptive alterations in cardiac structure and function in response to metabolic stress. However, since a-klotho and $\beta$-klotho, the established co-receptors for FGF23 and FGF19/21, respectively, are not expressed in the heart $(40,115)$, direct cardiac effects of endocrine FGFs are not expected. Nevertheless, recent translational studies have indicated that FGF21 and FGF23 can regulate cardiac remodeling, which might be at least partially due to their direct actions on the myocardium. Cardiac effects of FGF19 have not been reported to date.

It has been shown that short-term elevation of circulating FGF21 has cardio-protective effects in animal and ex vivo models of myocardial infarct, ischemia/reperfusion injury and $\beta$-adrenergic activation (156-160). In scenarios of cardiac injury, FGF21 enhances capillary density (158), inhibits inflammation $(156,158,159,161)$, promotes fatty acid oxidation $(156,161)$ and blocks lipid accumulation (162). In cardiac myocytes, FGF21 seems to 
suppress oxidative stress (159) and apoptosis $(157,158,161)$. Furthermore, cardiac myocytes secret FGF21 as an autocrine factor to protect themselves against oxidative stress, mitochondrial dysfunction, endoplasmic reticulum stress and hypertrophic stimuli and the heart from adverse cardiac remodeling $(156,159-161,163)$. Although it has been originally reported that $\beta$-klotho is not expressed in the heart $(40,115)$, more recent studies showed expression of $\beta$-klotho and activation of Ras/MAPK and PI3K/Akt signaling following FGF21 stimulation in cardiac myocytes $(156,157,160,164)$. It seems that as in other established FGF21 target cell types, FGFR1/ $\beta$-klotho mediates effects of FGF21 in cardiac myocytes. Future studies involving animal models with cardiac myocyte-specific deletion of FGF21 and the FGF21 receptor are needed to distinguish between cardiac effects that are mediated by FGF21's systemic metabolic versus direct cardiac actions and between the role of liver-derived, circulating FGF21 versus FGF21 that is produced in the myocardium.

Recent clinical studies have reported correlations between serum FGF21 levels and cardiovascular disease, such as hypertension (165), coronary artery disease $(166,167)$, acute myocardial infarction (168), atrial fibrillation (169) and atrial fibrosis (170). In patients with end-stage heart failure, serum and cardiac levels of FGF21 are significantly elevated (159), and circulating FGF21 concentrations correlate with cardiac hypertrophy and diastolic dysfunction (171). Combined these clinical observations suggest that FGF21 might be involved in pathological myocardial remodeling. This finding appears to be paradox to FGF21's cardio-protective effects in the described experimental studies and to its established beneficial functions in other tissues. Clearly, animal studies that describe the precise cardiac effects of FGF21 elevation in a time- and concentration-dependent manner as well as the identification and deletion of the putative FGF21 receptor(s) in cardiac myocytes are needed in order to determine if FGF21 effects on the heart are beneficial and/or pathological and occur in a direct and/or indirect manner.

Since serum levels of FGF21 are significantly elevated in diabetes, the potential role of FGF21 in associated cardiac pathologies, also termed diabetic cardiomyopathy, is of particular interest. In patients with type 2-diabets, serum FGF21 levels are associated with cardiovascular events and mortality $(172,173)$, indicating that FGF21 might contribute to cardiac injury. In contrast, in animal models of hyperglycemia, deletion of FGF21 exacerbates cardiac remodeling and dysfunction and cardiac myocyte apoptosis $(162,164)$, and elevation of FGF21 expression in the heart prevents cardiac fibrosis and inflammation (174). It is possible that as in other organs diabetes reflects an induced state of FGF21 resistance and that not direct pathological effects of FGF21 but rather the absence of its protective actions contribute cardiac injury. This is supported by a recent experimental study in an animal model for obesity with insulin-resistance, showing that long-term administration of FGF21 improves FGF21 sensitivity and attenuates cardiac dysfunction (161).

It has been recently shown that in the absence of a-klotho, FGF23 can elevate intracellular calcium levels in isolated cardiac myocytes as well as increase contractility in primary cardiac myocytes and ventricular muscle strips from mice (175). Whereas a-klothoexpressing cells respond to FGF23 by activating the Ras/MAPK cascade (30), FGF23 activates the PLC $\gamma /$ calcineurin/NFAT signaling axis in myocytes thereby promoting cardiac 
hypertrophy $(41,176)$. These in vitro findings have been supported by data derived from different rodent models with elevated serum FGF23 levels, such as injections of recombinant FGF23 in wild-type mice, renal ablation in rats, a-klotho deficiency in mice, and application of a high phosphate or adenine diet in mice, showing the development of cardiac hypertrophy (41, 176-178). This is the first example of a a-klotho-independent biological effect of FGF23 and suggests that the presence of a-klotho is not a prerequisite for FGF23responsivness. It also indicates that the heart might be capable of directly responding to circulating FGF23 (179).

In vitro screens to identify FGFR isoforms that could mediate FGF23's a-klothoindependent signaling revealed FGFR4 as the mediating receptor (41). Deletion or blockade of FGFR4 protects cultured cardiac myocytes from FGF23-induced hypertrophy and mice with elevated serum FGF23 from developing cardiac hypertrophy (41). The finding that rodent models with elevated serum FGF23 as well as knockin mice with a constitutively active FGFR4 mutation and normal serum FGF23 (as described earlier) show increased cardiac PLC $\gamma /$ calcineurin/NFAT signaling and develop cardiac hypertrophy (41), suggests that FGF23/FGFR4 signaling acts as a potent pro-hypertrophic signaling pathway in the heart.

Based on previous biochemical binding studies, the finding that in the absence of a-klotho FGFR4 but none of the other FGFR isoforms is activated by FGF23 is somewhat surprising. Surface plasmon resonance spectroscopy has revealed that FGF23 can bind FGFR4 with similar affinity as FGFR2c and with only slightly higher affinity than FGFR1c and FGFR3c (180). The low affinity of FGF23 for FGFR1c is increased by the presence of a-klotho by about 20 fold (181). The effect of a-klotho on FGF23's binding affinity for other FGFR isoforms has not been reported so far. Furthermore a functional in vitro screen has shown that at high treatment concentrations, FGF23 can induce cell proliferation to a similar degree in cells exclusively overexpressing FGFR1c, FGFR2c, FGFR3c or FGFR4 (180). Combined, these studies indicate that FGF23 can bind different FGFR isoforms, including FGFR4, with low affinity. However it remains unclear why within the FGFR family, FGFR4 would have the highest affinity for FGF23. It is possible that cells that lack a-klotho but can respond to FGF23 under pathophysiologic conditions, such as cardiac myocytes, express other coreceptor(s) for FGF23 binding that might specifically interact with FGFR4. However, to date such factors have not been identified.

\section{The role of FGF23 in uremic cardiomyopathy}

Chronic kidney disease (CKD) is a public health epidemic that affects approximately 26 million Americans and many more individuals worldwide (182). The presence of CKD increases risk of premature death, and cardiovascular disease is the leading cause at all stages of CKD (183). Although there is a high prevalence of conventional cardiovascular risk factors in the CKD population, the relationship between these factors and outcome is less clear than in the general population $(184,185)$. Hypertension is common in CKD, and it has been hypothesized that cardiac hypertrophy develops as a result of pressure overload (186). However, correction of hypertension in animal models with renal injury does not always prevent hypertrophy (187-189). Complications in mineral metabolism, including 
elevated serum levels of phosphate and FGF23, are common in CKD and associate with cardiovascular disease, especially with cardiac hypertrophy, also termed uremic cardiomyopathy, and with mortality (176, 190-197). Based on the observed FGF23 effects on cultured cardiac myocytes, it is possible that elevated FGF23 might act as a causal factor in the pathogenesis of uremic cardiomyopathy thereby repositioning FGF23 from biomarker of risk to mechanism of disease.

As FGFR4 expression levels and NFAT activity are increased in cardiac tissue from individuals with CKD that had developed cardiac hypertrophy, when compared to CKD patients without cardiac hypertrophy (42), FGF23/FGFR4 signaling has emerged as a novel therapeutic target in CKD $(41,198)$. However, recent clinical and animal studies have shown that FGF23 reduction by phosphate binders and systemic FGF23 inhibitors lack sufficient safety and effectiveness $(199,200)$. Complete abrogation of FGF23 function causes severe hyperphosphatemia resulting in aggressive vascular calcification and increased mortality (200). In contrast, FGFR4 blockade might serve as a novel and safe pharmacological intervention for cardiac hypertrophy in patients with CKD (41). It is possible that FGFR4 blockade can selectively interfere with FGF23's pathological cardiac effects, while retaining the desirable physiological functions of FGF23 that are primarily dependent on FGFR1 (30, 31). In line with this hypothesis, constitutive FGFR4 knockout mice do not exhibit a severe phenotype $(201,202)$.

Recent research has revealed that several different cell types can respond to FGF23 (203, 204). Therefore, the generation of conditional knockout mouse lines for cardiac myocytespecific deletion of FGFR4 and cardiac analysis following FGF23 elevation as well as coculture studies using isolated cardiac myocytes in combination with non-myocytes, such as fibroblasts, will be necessary to determine if indeed cardiac myocytes serve as direct target for FGF23 and/or if other cardiac cell types receive the initial FGF23 hit and hypertrophic myocyte growth occurs secondarily in response to other events, such as fibrosis or angiogenesis. To date, it is not clear if FGF23 can target fibroblasts, in the heart or elsewhere, and if it has pro-fibrotic effects as some of the other FGF family members. It is also not established if FGF23 can directly target endothelial cells or vascular smooth muscle cells and contribute to cardio-angiogenesis, as shown for other FGF isoforms. Based on the cardiac actions of paracrine FGFs (as described above) it would be not surprising if FGF23 could also promote cardiac fibrosis and/or angiogenesis that could then contribute to FGF23mediated cardiac remodeling. Furthermore, a genome-wide analysis of FGF23-regulated genes in mouse models with elevated FGF23 suggests inflammatory cytokine genes as FGF23 targets (205), and experimental studies have shown that FGF23 stimulates expression of inflammatory cytokines in macrophages (206, 207), spleen (208) and hepatocytes (204). Therefore, FGF23 might have general pro-inflammatory features that might contribute to cardiac inflammation associated with pathologic hypertrophy. If FGF23 can induce expression and secretion of inflammatory cytokines in cardiac cells such as myocytes and/or contributes to the infiltration and activation of inflammatory cells in the heart needs to be established.

Hypertension is a common feature of CKD and by itself a potent inducer of cardiac hypertrophy. Although some treatment studies in animal models of CKD show a reduction 
of cardiac hypertrophy without lowering blood pressure (41, 59, 176, 198, 209-211), thereby uncoupling cardiac injury from hypertension in the context of kidney injury, it is most likely that in CKD increases in blood pressure together with a variety of other factors, such as serum elevations of FGF23 and uremic toxins (212), synergistically contribute to cardiac injury. In fact, FGF23 might directly contribute to hypertension by targeting the renal renin-angiotensin system (205) and by regulating renal sodium handling via targeting the distal tubules (213). Interestingly, a recent study indicates that FGF23's hypertensive effects might be required for the development of cardiac hypertrophy in mice (213).

Serum FGF23 levels do not only associate with cardiac hypertrophy in the CKD population, but also in cardiovascular cohorts with no or only slightly impaired renal function (214219). Furthermore, elevated serum FGF23 levels associate with primary cardiac injury in a mouse model for myocardial infarct (220). These studies suggest that elevated serum FGF23 might contribute to primary cardiac injury in the absence of kidney injury. It this scenario an unknown endocrine heart-bone feedback mechanism might elevate FGF23 synthesis and secretion in bone following cardiac injury $(219,220)$. Since the injured heart releases proinflammatory cytokines, and inflammatory cytokines can directly increase production of FGF23 in bone (221-223), it is possible that such cytokines together with FGF23 serve as a bidirectional communication route between bone and heart that might provide the bone with the capability to regulate cardiac remodeling and vice versa enable the heart to control phosphate homeostasis. An alternative explanation for the source of FGF23 in the context of primary cardiac injury would be the existence of a paracrine mechanism in the heart. In fact, it has been shown that cardiac myocytes can produce FGF23, and that myocardial FGF23 levels are elevated in patients with dilated cardiomyopathy and ischemic heart disease as well as in mice with inflammatory heart failure $(224,225)$. Furthermore, systemic inflammation elevates FGF23 expression in cardiac fibroblasts (226, 227). Myocardial FGF23 expression has been also reported in patients with CKD, where levels positively correlate with the development of cardiac hypertrophy (42).

Overall, it seems that myocardial and circulating levels of FGF23 associate with cardiac hypertrophy in CKD and non-CKD. Future animal studies should aim to determine if paracrine and endocrine FGF23 differ in their ability to target the heart and to contribute to cardiac hypertrophy and heart failure. Furthermore, it appears that inflammatory cytokines and FGF23 together are part of positive regulatory cycle where FGF23 increases cytokine release in cardiac cells and macrophages and cytokines contribute to increased FGF23 production in bone and heart. The precise characterization of molecular and cellular events in relation to time and concentrations of FGF23 exposure will be necessary to determine if FGF23's cardiac effects are purely pathologic, or originally beneficial and eventually transition into maladaptive events. It would be interesting to determine if FGF23 can aggravate cardiac hypertrophy induced by other pathologic stimuli, or convey cardioprotection in the presence of cardiac stress stimuli, as shown for other FGFs and discussed above. Since in CKD serum and cardiac FGF23 levels correlate with serum phosphate (42), it is possible that hyperphosphatemia might serve as such a cardiac stressor, but precise actions of high phosphate levels on the myocardium are not well described. 
Of note, since knockin mice with constitutive FGFR4 activation develop cardiac hypertrophy (41), it is possible that FGFR4 might serve as a novel drug target for the pathological hypertrophy associate with non-renal etiologies. If future studies can confirm that FGFR4 activation per se is sufficient to induce pathological cardiac hypertrophy and that cardiac FGFR4 activation is a feature in animal models of heart failure, it is possible that FGFR4 serves as a component of a novel hypertrophic signaling pathway that is generally activated in patients with heart disease marked by aberrant cardiac remodeling. In the United States, heart failure affects 5.1 million people, and each year 825,000 new cases are diagnosed (228). The prevalence and incidence of heart failure are increasing, because of increasing life span, the increased prevalence of risk factors (hypertension, diabetes, dyslipidemia, and obesity) and the improved survival rates from other types of cardiovascular disease such as myocardial infarction and arrhythmias. However despite current therapies, the 5-year mortality for heart failure remains $50 \%$, making it necessary to derive new therapies for the treatment of cardiac diseases. FGFR4 blockade might serve as such a novel pharmacological approach.

\section{A potential role of other FGF family members in uremic cardiomyopathy}

Besides FGF23, also some of the other FGF family members have been linked to CKD. Cardiac expression of FGF2 is significantly elevated in a rat model of CKD, and treatment with the antioxidant apocynin reduces FGF2 expression as well as cardiac hypertrophy and fibrosis (229). Mice with global FGF2 deletion are protected from developing compensatory cardiac hypertrophy following surgically induced reno-vascular hypertension (69). Therefore, it is likely that cardiac FGF2 might directly contribute to uremic cardiomyopathy. Furthermore, it is possible that the two other members of the endocrine FGF subfamily, i.e. FGF19 and FGF21, can tackle the heart in the context of kidney injury. While experimental data to support such a hypothesis are still missing, clinical studies have shown that serum levels of FGF19 (230) and FGF21 (231-234) are elevated in CKD patients. One study also reported that serum FGF21 levels are higher in CKD patients with than without cardiac hypertrophy (235). It will be interesting to determine serum levels of FGF19 and FGF21 and associations with cardiac alterations in larger CKD populations and to experimentally determine their potentially direct actions on the heart as well as causality between serum levels and cardiac injury.

\section{Conclusion}

A variety of in vitro and in vivo studies have indicated that FGF/FGFR signaling provides an important base for the paracrine and endocrine regulation of cardiac remodeling. However, if these effects stem from direct activation the signaling system in cardiac myocytes is not fully understood. Since several FGF family members activate fibroblasts and induce angiogenesis and might also elevate blood pressure, FGFs have the potential to indirectly contribute to cardiac remodeling. If FGF/FGFR signaling per se can initiate changes in cardiac function and structure, or only modulates cardiac remodeling in concert with other cardio-toxic factors remains unclear. Furthermore, whether FGF/FGFR signaling fulfills physiologic functions in the heart or purely mediates pathologic effects leading to cardiac injury is not known. The precise characterization of cardiac events driven by FGF/FGFR activity is 
necessary, in order to determine whether the development of pharmacologic agonists or antagonists for FGF/FGFR signaling is desirable. Most likely, the cardiac scenario depends on the nature of the underlying primary injury and the associated secondary pathologies. In recent years, this scenario has become clearer in uremic cardiomyopathy. Based on the strong associations between elevated serum FGF23 levels and cardiac injury in CKD and mechanistic studies showing that FGF23 can activate FGFR4 in the heart, FGF23 appears to be a major driver of uremic cardiomyopathy. Studies in uremic rodent models have indicated that pharmacological inhibition of all FGFR isoforms as well as specifically of FGFR4 protects the heart and even prevents or reverses cardiac injury. Therefore, FGFR4 blockade might appear as a novel cardio-protective therapy in patients with CKD. It will be worthwhile to experimentally determine the causative involvement of FGF signaling events in other cardiac pathologies, such as FGF21/FGFR1/ $\beta$-klotho in diabetic cardiomyopathy, and FGF2/FGFR1 in the progression of pathologic cardiac hypertrophy to heart failure.

\section{ACKNOWLEDGEMENTS}

This work was supported by the Katz Family Drug Discovery Center of the University of Miami Miller School of Medicine, the R01HL128714 grant from the National Institutes of Health, and the Innovative Basic Science Award 1-16-IBS-087 of the American Diabetes Association. Dr. Faul has served as a consultant for Ultragenyx and has received research support from U3 Pharma GmbH and Hoffman-La Roche.

\section{ABBREVIATIONS}

\begin{tabular}{ll} 
AngII & angiotensin II \\
CKD & chronic kidney disease \\
EGF & epidermal growth factor \\
FGF & fibroblast growth factor \\
FGFR & fibroblast growth factor receptor \\
FRS2 $\boldsymbol{F}$ & FGF receptor substrate 2a \\
HPG & heparan sulfate proteoglycans \\
IGF-1 & insulin-like growth factor 1 \\
IP3 & inositol 1,4,5-triphosphate \\
MAPK & mitogen-activated protein kinase \\
NFAT & nuclear factor of activated T-cells \\
PI3K & phosphatidylinositol 3'-kinase \\
PLC $\boldsymbol{\gamma}$ & phospholipase C $\boldsymbol{\gamma}$ \\
PTH & parathyroid hormone \\
qPC & quantitative real-time PCR \\
\hline
\end{tabular}




\section{REFERENCES}

1. Hill JA, Olson EN. Cardiac plasticity. N Engl J Med. 2008; 358:1370-1380. [PubMed: 18367740]

2. Burchfield JS, Xie M, Hill JA. Pathological ventricular remodeling: mechanisms: part 1 of 2. Circulation. 2013; 128:388-400. [PubMed: 23877061]

3. Frey N, Olson EN. Cardiac hypertrophy: the good, the bad, and the ugly. Annu Rev Physiol. 2003; 65:45-79. [PubMed: 12524460]

4. Krenning G, Zeisberg EM, Kalluri R. The origin of fibroblasts and mechanism of cardiac fibrosis. J Cell Physiol. 2010; 225:631-637. [PubMed: 20635395]

5. Souders CA, Bowers SL, Baudino TA. Cardiac fibroblast: the renaissance cell. Circ Res. 2009; 105:1164-1176. [PubMed: 19959782]

6. Parker TG, Schneider MD. Growth factors, proto-oncogenes, and plasticity of the cardiac phenotype. Annu Rev Physiol. 1991; 53:179-200. [PubMed: 2042959]

7. Manabe I, Shindo T, Nagai R. Gene expression in fibroblasts and fibrosis: involvement in cardiac hypertrophy. Circ Res. 2002; 91:1103-1113. [PubMed: 12480810]

8. Troncoso R, Ibarra C, Vicencio JM, Jaimovich E, Lavandero S. New insights into IGF-1 signaling in the heart. Trends Endocrinol Metab. 2014; 25:128-137. [PubMed: 24380833]

9. Maillet M, van Berlo JH, Molkentin JD. Molecular basis of physiological heart growth: fundamental concepts and new players. Nat Rev Mol Cell Biol. 2013; 14:38-48. [PubMed: 23258295]

10. Chung E, Leinwand LA. Pregnancy as a cardiac stress model. Cardiovasc Res. 2014; 101:561-570. [PubMed: 24448313]

11. Crone SA, Zhao YY, Fan L, Gu Y, Minamisawa S, Liu Y, Peterson KL, Chen J, Kahn R, Condorelli G, et al. ErbB2 is essential in the prevention of dilated cardiomyopathy. Nat Med. 2002; 8:459465. [PubMed: 11984589]

12. Ozcelik C, Erdmann B, Pilz B, Wettschureck N, Britsch S, Hubner N, Chien KR, Birchmeier C, Garratt AN. Conditional mutation of the ErbB2 (HER2) receptor in cardiomyocytes leads to dilated cardiomyopathy. Proc Natl Acad Sci U S A. 2002; 99:8880-8885. [PubMed: 12072561]

13. Fukazawa R, Miller TA, Kuramochi Y, Frantz S, Kim YD, Marchionni MA, Kelly RA, Sawyer DB. Neuregulin-1 protects ventricular myocytes from anthracycline-induced apoptosis via erbB4dependent activation of PI3-kinase/Akt. J Mol Cell Cardiol. 2003; 35:1473-1479. [PubMed: 14654373]

14. Lemmens K, Segers VF, Demolder M, De Keulenaer GW. Role of neuregulin-1/ErbB2 signaling in endothelium-cardiomyocyte cross-talk. J Biol Chem. 2006; 281:19469-19477. [PubMed: 16698793]

15. Lemmens K, Doggen K, De Keulenaer GW. Role of neuregulin-1/ErbB signaling in cardiovascular physiology and disease: implications for therapy of heart failure. Circulation. 2007; 116:954-960. [PubMed: 17709650]

16. De Keulenaer GW, Doggen K, Lemmens K. The vulnerability of the heart as a pluricellular paracrine organ: lessons from unexpected triggers of heart failure in targeted ErbB2 anticancer therapy. Circ Res. 2010; 106:35-46. [PubMed: 20056944]

17. Itoh N, Ohta H. Pathophysiological roles of FGF signaling in the heart. Front Physiol. 2013; 4:247. [PubMed: 24046748]

18. Itoh N, Ornitz DM. Evolution of the Fgf and Fgfr gene families. Trends Genet. 2004; 20:563-569. [PubMed: 15475116]

19. Szebenyi G, Fallon JF. Fibroblast growth factors as multifunctional signaling factors. Int Rev Cytol. 1999; 185:45-106. [PubMed: 9750265]

20. Eswarakumar VP, Lax I, Schlessinger J. Cellular signaling by fibroblast growth factor receptors. Cytokine Growth Factor Rev. 2005; 16:139-149. [PubMed: 15863030]

21. Itoh N, Ornitz DM. Fibroblast growth factors: from molecular evolution to roles in development, metabolism and disease. J Biochem. 2011; 149:121-130. [PubMed: 20940169]

22. Goldfarb M, Schoorlemmer J, Williams A, Diwakar S, Wang Q, Huang X, Giza J, Tchetchik D, Kelley K, Vega A, et al. Fibroblast growth factor homologous factors control neuronal excitability 
through modulation of voltage-gated sodium channels. Neuron. 2007; 55:449-463. [PubMed: 17678857]

23. Laezza F, Lampert A, Kozel MA, Gerber BR, Rush AM, Nerbonne JM, Waxman SG, Dib-Hajj SD, Ornitz DM. FGF14 N-terminal splice variants differentially modulate Nav1.2 and Nav1.6-encoded sodium channels. Mol Cell Neurosci. 2009; 42:90-101. [PubMed: 19465131]

24. Yayon A, Klagsbrun M, Esko JD, Leder P, Ornitz DM. Cell surface, heparin-like molecules are required for binding of basic fibroblast growth factor to its high affinity receptor. Cell. 1991; 64:841-848. [PubMed: 1847668]

25. Rapraeger AC, Krufka A, Olwin BB. Requirement of heparan sulfate for bFGF-mediated fibroblast growth and myoblast differentiation. Science. 1991; 252:1705-1708. [PubMed: 1646484]

26. Spivak-Kroizman T, Lemmon MA, Dikic I, Ladbury JE, Pinchasi D, Huang J, Jaye M, Crumley G, Schlessinger J, Lax I. Heparin-induced oligomerization of FGF molecules is responsible for FGF receptor dimerization, activation, and cell proliferation. Cell. 1994; 79:1015-1024. [PubMed: 7528103]

27. Goetz R, Beenken A, Ibrahimi OA, Kalinina J, Olsen SK, Eliseenkova AV, Xu C, Neubert TA, Zhang F, Linhardt RJ, et al. Molecular insights into the klotho-dependent, endocrine mode of action of fibroblast growth factor 19 subfamily members. Mol Cell Biol. 2007; 27:3417-3428. [PubMed: 17339340]

28. Harmer NJ, Pellegrini L, Chirgadze D, Fernandez-Recio J, Blundell TL. The crystal structure of fibroblast growth factor (FGF) 19 reveals novel features of the FGF family and offers a structural basis for its unusual receptor affinity. Biochemistry. 2004; 43:629-640. [PubMed: 14730967]

29. Mohammadi M, Olsen SK, Ibrahimi OA. Structural basis for fibroblast growth factor receptor activation. Cytokine Growth Factor Rev. 2005; 16:107-137. [PubMed: 15863029]

30. Urakawa I, Yamazaki Y, Shimada T, Iijima K, Hasegawa H, Okawa K, Fujita T, Fukumoto S, Yamashita T. Klotho converts canonical FGF receptor into a specific receptor for FGF23. Nature. 2006; 444:770-774. [PubMed: 17086194]

31. Kurosu H, Ogawa Y, Miyoshi M, Yamamoto M, Nandi A, Rosenblatt KP, Baum MG, Schiavi S, $\mathrm{Hu} \mathrm{MC}$, Moe OW, et al. Regulation of fibroblast growth factor-23 signaling by klotho. J Biol Chem. 2006; 281:6120-6123. [PubMed: 16436388]

32. Kuro-o M, Matsumura Y, Aizawa H, Kawaguchi H, Suga T, Utsugi T, Ohyama Y, Kurabayashi M, Kaname T, Kume E, et al. Mutation of the mouse klotho gene leads to a syndrome resembling ageing. Nature. 1997; 390:45-51. [PubMed: 9363890]

33. Ben-Dov IZ, Galitzer H, Lavi-Moshayoff V, Goetz R, Kuro-o M, Mohammadi M, Sirkis R, NavehMany T, Silver J. The parathyroid is a target organ for FGF23 in rats. J Clin Invest. 2007; 117:4003-4008. [PubMed: 17992255]

34. Ornitz DM, Itoh N. Fibroblast growth factors. Genome Biol. 2001; 2 REVIEWS3005.

35. Turner N, Grose R. Fibroblast growth factor signalling: from development to cancer. Nat Rev Cancer. 2010; 10:116-129. [PubMed: 20094046]

36. Mohammadi M, Honegger AM, Rotin D, Fischer R, Bellot F, Li W, Dionne CA, Jaye M, Rubinstein M, Schlessinger J. A tyrosine-phosphorylated carboxy-terminal peptide of the fibroblast growth factor receptor (Flg) is a binding site for the SH2 domain of phospholipase Cgamma 1. Mol Cell Biol. 1991; 11:5068-5078. [PubMed: 1656221]

37. Vainikka S, Joukov V, Wennstrom S, Bergman M, Pelicci PG, Alitalo K. Signal transduction by fibroblast growth factor receptor-4 (FGFR-4). Comparison with FGFR-1. J Biol Chem. 1994; 269:18320-18326. [PubMed: 7518429]

38. Burgess WH, Dionne CA, Kaplow J, Mudd R, Friesel R, Zilberstein A, Schlessinger J, Jaye M. Characterization and cDNA cloning of phospholipase C-gamma, a major substrate for heparinbinding growth factor 1 (acidic fibroblast growth factor)-activated tyrosine kinase. Mol Cell Biol. 1990; 10:4770-4777. [PubMed: 2167438]

39. Kouhara H, Hadari YR, Spivak-Kroizman T, Schilling J, Bar-Sagi D, Lax I, Schlessinger J. A lipidanchored Grb2-binding protein that links FGF-receptor activation to the Ras/MAPK signaling pathway. Cell. 1997; 89:693-702. [PubMed: 9182757] 
40. Fon Tacer K, Bookout AL, Ding X, Kurosu H, John GB, Wang L, Goetz R, Mohammadi M, Kuroo M, Mangelsdorf DJ, et al. Research resource: Comprehensive expression atlas of the fibroblast growth factor system in adult mouse. Mol Endocrinol. 2010; 24:2050-2064. [PubMed: 20667984]

41. Grabner A, Amaral AP, Schramm K, Singh S, Sloan A, Yanucil C, Li J, Shehadeh LA, Hare JM, David V, et al. Activation of Cardiac Fibroblast Growth Factor Receptor 4 Causes Left Ventricular Hypertrophy. Cell Metab. 2015

42. Leifheit-Nestler M, Grosse Siemer R, Flasbart K, Richter B, Kirchhoff F, Ziegler WH, Klintschar M, Becker JU, Erbersdobler A, Aufricht C, et al. Induction of cardiac FGF23/FGFR4 expression is associated with left ventricular hypertrophy in patients with chronic kidney disease. Nephrol Dial Transplant. 2015

43. Hughes SE. Differential expression of the fibroblast growth factor receptor (FGFR) multigene family in normal human adult tissues. J Histochem Cytochem. 1997; 45:1005-1019. [PubMed: 9212826]

44. Sheikh F, Fandrich RR, Kardami E, Cattini PA. Overexpression of long or short FGFR-1 results in FGF-2-mediated proliferation in neonatal cardiac myocyte cultures. Cardiovasc Res. 1999; 42:696-705. [PubMed: 10533610]

45. Zhao T, Zhao W, Chen Y, Ahokas RA, Sun Y. Acidic and basic fibroblast growth factors involved in cardiac angiogenesis following infarction. Int J Cardiol. 2011; 152:307-313. [PubMed: 20674996]

46. Speir E, Tanner V, Gonzalez AM, Farris J, Baird A, Casscells W. Acidic and basic fibroblast growth factors in adult rat heart myocytes. Localization, regulation in culture, and effects on DNA synthesis. Circ Res. 1992; 71:251-259. [PubMed: 1378359]

47. Liu L, Pasumarthi KB, Padua RR, Massaeli H, Fandrich RR, Pierce GN, Cattini PA, Kardami E. Adult cardiomyocytes express functional high-affinity receptors for basic fibroblast growth factor. Am J Physiol. 1995; 268:H1927-1938. [PubMed: 7771542]

48. Cilvik SN, Wang JI, Lavine KJ, Uchida K, Castro A, Gierasch CM, Weinheimer CJ, House SL, Kovacs A, Nichols CG, et al. Fibroblast growth factor receptor 1 signaling in adult cardiomyocytes increases contractility and results in a hypertrophic cardiomyopathy. PLoS One. 2013; 8:e82979. [PubMed: 24349409]

49. Lavine KJ, Yu K, White AC, Zhang X, Smith C, Partanen J, Ornitz DM. Endocardial and epicardial derived FGF signals regulate myocardial proliferation and differentiation in vivo. Dev Cell. 2005; 8:85-95. [PubMed: 15621532]

50. Vega-Hernandez M, Kovacs A, De Langhe S, Ornitz DM. FGF10/FGFR2b signaling is essential for cardiac fibroblast development and growth of the myocardium. Development. 2011; 138:33313340. [PubMed: 21750042]

51. Marguerie A, Bajolle F, Zaffran S, Brown NA, Dickson C, Buckingham ME, Kelly RG. Congenital heart defects in Fgfr2-IIIb and Fgf10 mutant mice. Cardiovasc Res. 2006; 71:50-60. [PubMed: 16687131]

52. Stark KL, McMahon JA, McMahon AP. FGFR-4, a new member of the fibroblast growth factor receptor family, expressed in the definitive endoderm and skeletal muscle lineages of the mouse. Development. 1991; 113:641-651. [PubMed: 1723680]

53. Partanen J, Makela TP, Eerola E, Korhonen J, Hirvonen H, Claesson-Welsh L, Alitalo K. FGFR-4, a novel acidic fibroblast growth factor receptor with a distinct expression pattern. EMBO J. 1991; 10:1347-1354. [PubMed: 1709094]

54. Seitzer N, Mayr T, Streit S, Ullrich A. A single nucleotide change in the mouse genome accelerates breast cancer progression. Cancer Res. 2010; 70:802-812. [PubMed: 20068154]

55. Jiang ZS, Padua RR, Ju H, Doble BW, Jin Y, Hao J, Cattini PA, Dixon IM, Kardami E. Acute protection of ischemic heart by FGF-2: involvement of FGF-2 receptors and protein kinase C. Am J Physiol Heart Circ Physiol. 2002; 282:H1071-1080. [PubMed: 11834506]

56. Htun P, Ito WD, Hoefer IE, Schaper J, Schaper W. Intramyocardial infusion of FGF-1 mimics ischemic preconditioning in pig myocardium. J Mol Cell Cardiol. 1998; 30:867-877. [PubMed: 9602436] 
57. Lepilina A, Coon AN, Kikuchi K, Holdway JE, Roberts RW, Burns CG, Poss KD. A dynamic epicardial injury response supports progenitor cell activity during zebrafish heart regeneration. Cell. 2006; 127:607-619. [PubMed: 17081981]

58. Freundlich M, Li YC, Quiroz Y, Bravo Y, Seeherunvong W, Faul C, Weisinger JR, RodriguezIturbe B. Paricalcitol downregulates myocardial renin-angiotensin and fibroblast growth factor expression and attenuates cardiac hypertrophy in uremic rats. Am J Hypertens. 2014; 27:720-726. [PubMed: 24072555]

59. Di Marco GS, Reuter S, Kentrup D, Ting L, Grabner A, Jacobi AM, Pavenstadt H, Baba HA, Tiemann K, Brand M. Cardioprotective effect of calcineurin inhibition in an animal model of renal disease. Eur Heart J. 2011; 32:1935-1945. [PubMed: 21138940]

60. Oliveras-Ferraros C, Cufi S, Queralt B, Vazquez-Martin A, Martin-Castillo B, de Llorens R, Bosch-Barrera J, Brunet J, Menendez JA. Cross-suppression of EGFR ligands amphiregulin and epiregulin and de-repression of FGFR3 signalling contribute to cetuximab resistance in wild-type KRAS tumour cells. Br J Cancer. 2012; 106:1406-1414. [PubMed: 22491422]

61. Wesche J, Haglund K, Haugsten EM. Fibroblast growth factors and their receptors in cancer. Biochem J. 2011; 437:199-213. [PubMed: 21711248]

62. Yanochko GM, Vitsky A, Heyen JR, Hirakawa B, Lam JL, May J, Nichols T, Sace F, Trajkovic D, Blasi E. Pan-FGFR inhibition leads to blockade of FGF23 signaling, soft tissue mineralization, and cardiovascular dysfunction. Toxicol Sci. 2013; 135:451-464. [PubMed: 23872713]

63. Kardami E, Jiang ZS, Jimenez SK, Hirst CJ, Sheikh F, Zahradka P, Cattini PA. Fibroblast growth factor 2 isoforms and cardiac hypertrophy. Cardiovasc Res. 2004; 63:458-466. [PubMed: 15276471]

64. Kardami E, Detillieux K, Ma X, Jiang Z, Santiago JJ, Jimenez SK, Cattini PA. Fibroblast growth factor-2 and cardioprotection. Heart Fail Rev. 2007; 12:267-277. [PubMed: 17516168]

65. Cummins P. Fibroblast and transforming growth factor expression in the cardiac myocyte. Cardiovasc Res. 1993; 27:1150-1154. [PubMed: 8252573]

66. Parker TG, Packer SE, Schneider MD. Peptide growth factors can provoke "fetal" contractile protein gene expression in rat cardiac myocytes. J Clin Invest. 1990; 85:507-514. [PubMed: 1688886]

67. Kaye D, Pimental D, Prasad S, Maki T, Berger HJ, McNeil PL, Smith TW, Kelly RA. Role of transiently altered sarcolemmal membrane permeability and basic fibroblast growth factor release in the hypertrophic response of adult rat ventricular myocytes to increased mechanical activity in vitro. J Clin Invest. 1996; 97:281-291. [PubMed: 8567946]

68. Corda S, Mebazaa A, Gandolfini MP, Fitting C, Marotte F, Peynet J, Charlemagne D, Cavaillon JM, Payen D, Rappaport L, et al. Trophic effect of human pericardial fluid on adult cardiac myocytes. Differential role of fibroblast growth factor-2 and factors related to ventricular hypertrophy. Circ Res. 1997; 81:679-687. [PubMed: 9351441]

69. Pellieux C, Foletti A, Peduto G, Aubert JF, Nussberger J, Beermann F, Brunner HR, Pedrazzini T. Dilated cardiomyopathy and impaired cardiac hypertrophic response to angiotensin II in mice lacking FGF-2. J Clin Invest. 2001; 108:1843-1851. [PubMed: 11748268]

70. Santiago JJ, McNaughton LJ, Koleini N, Ma X, Bestvater B, Nickel BE, Fandrich RR, Wigle JT, Freed DH, Arora RC, et al. High molecular weight fibroblast growth factor- 2 in the human heart is a potential target for prevention of cardiac remodeling. PLoS One. 2014; 9:e97281. [PubMed: 24827991]

71. Merle PL, Feige JJ, Verdetti J. Basic fibroblast growth factor activates calcium channels in neonatal rat cardiomyocytes. J Biol Chem. 1995; 270:17361-17367. [PubMed: 7615540]

72. Cui G, Chen H, Cui W, Guo X, Fang J, Liu A, Chen Y, Lee SM. FGF2 Prevents Sunitinib-Induced Cardiotoxicity in Zebrafish and Cardiomyoblast H9c2 Cells. Cardiovasc Toxicol. 2016; 16:46-53. [PubMed: 25701259]

73. Bogoyevitch MA, Glennon PE, Andersson MB, Clerk A, Lazou A, Marshall CJ, Parker PJ, Sugden $\mathrm{PH}$. Endothelin-1 and fibroblast growth factors stimulate the mitogen-activated protein kinase signaling cascade in cardiac myocytes. The potential role of the cascade in the integration of two signaling pathways leading to myocyte hypertrophy. J Biol Chem. 1994; 269:1110-1119. [PubMed: 7507104] 
74. Padua RR, Merle PL, Doble BW, Yu CH, Zahradka P, Pierce GN, Panagia V, Kardami E. FGF-2induced negative inotropism and cardioprotection are inhibited by chelerythrine: involvement of sarcolemmal calcium-independent protein kinase C. J Mol Cell Cardiol. 1998; 30:2695-2709. [PubMed: 9990540]

75. Sheikh F, Sontag DP, Fandrich RR, Kardami E, Cattini PA. Overexpression of FGF-2 increases cardiac myocyte viability after injury in isolated mouse hearts. Am J Physiol Heart Circ Physiol. 2001; 280:H1039-1050. [PubMed: 11179045]

76. House SL, House BE, Glascock B, Kimball T, Nusayr E, Schultz JE, Doetschman T. Fibroblast Growth Factor 2 Mediates Isoproterenol-induced Cardiac Hypertrophy through Activation of the Extracellular Regulated Kinase. Mol Cell Pharmacol. 2010; 2:143-154. [PubMed: 21274419]

77. Muslin AJ. MAPK signalling in cardiovascular health and disease: molecular mechanisms and therapeutic targets. Clin Sci (Lond). 2008; 115:203-218. [PubMed: 18752467]

78. Tappia PS, Padua RR, Panagia V, Kardami E. Fibroblast growth factor-2 stimulates phospholipase Cbeta in adult cardiomyocytes. Biochem Cell Biol. 1999; 77:569-575. [PubMed: 10668634]

79. Liu X, Wu X, Cai L, Sun S. Calreticulin downregulation is associated with FGF-2-induced angiogenesis through calcineurin pathway in ischemic myocardium. Shock. 2008; 29:140-148. [PubMed: 17693930]

80. Srisakuldee W, Nickel BE, Fandrich RR, Jiang ZS, Kardami E. Administration of FGF-2 to the heart stimulates connexin-43 phosphorylation at protein kinase $\mathrm{C}$ target sites. Cell Commun Adhes. 2006; 13:13-19. [PubMed: 16613776]

81. House SL, Bolte C, Zhou M, Doetschman T, Klevitsky R, Newman G, Schultz Jel J. Cardiacspecific overexpression of fibroblast growth factor-2 protects against myocardial dysfunction and infarction in a murine model of low-flow ischemia. Circulation. 2003; 108:3140-3148. [PubMed: 14656920]

82. Scheinowitz M, Kotlyar AA, Zimand S, Leibovitz I, Varda-Bloom N, Ohad D, Goldberg I, Engelberg S, Savion N, Eldar M. Effect of basic fibroblast growth factor on left ventricular geometry in rats subjected to coronary occlusion and reperfusion. Isr Med Assoc J. 2002; 4:109_ 113. [PubMed: 11875982]

83. Fiebeler A, Schmidt F, Muller DN, Park JK, Dechend R, Bieringer M, Shagdarsuren E, Breu V, Haller H, Luft FC. Mineralocorticoid receptor affects AP-1 and nuclear factor-kappab activation in angiotensin II-induced cardiac injury. Hypertension. 2001; 37:787-793. [PubMed: 11230374]

84. Detillieux KA, Meij JT, Kardami E, Cattini PA. alpha1-Adrenergic stimulation of FGF-2 promoter in cardiac myocytes and in adult transgenic mouse hearts. Am J Physiol. 1999; 276:H826-833. [PubMed: 10070065]

85. Clarke MS, Caldwell RW, Chiao H, Miyake K, McNeil PL. Contraction-induced cell wounding and release of fibroblast growth factor in heart. Circ Res. 1995; 76:927-934. [PubMed: 7538917]

86. Meij JT, Sheikh F, Jimenez SK, Nickerson PW, Kardami E, Cattini PA. Exacerbation of myocardial injury in transgenic mice overexpressing FGF-2 is T cell dependent. Am J Physiol Heart Circ Physiol. 2002; 282:H547-555. [PubMed: 11788402]

87. Schultz JE, Witt SA, Nieman ML, Reiser PJ, Engle SJ, Zhou M, Pawlowski SA, Lorenz JN, Kimball TR, Doetschman T. Fibroblast growth factor-2 mediates pressure-induced hypertrophic response. J Clin Invest. 1999; 104:709-719. [PubMed: 10491406]

88. Virag JA, Rolle ML, Reece J, Hardouin S, Feigl EO, Murry CE. Fibroblast growth factor-2 regulates myocardial infarct repair: effects on cell proliferation, scar contraction, and ventricular function. Am J Pathol. 2007; 171:1431-1440. [PubMed: 17872976]

89. Jimenez SK, Jassal DS, Kardami E, Cattini PA. Protection by endogenous FGF-2 against isoproterenol-induced cardiac dysfunction is attenuated by cyclosporine A. Mol Cell Biochem. 2011; 357:1-8. [PubMed: 21556823]

90. Dono R, Texido G, Dussel R, Ehmke H, Zeller R. Impaired cerebral cortex development and blood pressure regulation in FGF-2-deficient mice. Embo J. 1998; 17:4213-4225. [PubMed: 9687490]

91. Zhou M, Sutliff RL, Paul RJ, Lorenz JN, Hoying JB, Haudenschild CC, Yin M, Coffin JD, Kong L, Kranias EG, et al. Fibroblast growth factor 2 control of vascular tone. Nat Med. 1998; 4:201-207. [PubMed: 9461194] 
92. Padua RR, Sethi R, Dhalla NS, Kardami E. Basic fibroblast growth factor is cardioprotective in ischemia-reperfusion injury. Mol Cell Biochem. 1995; 143:129-135. [PubMed: 7596347]

93. Kawasuji M, Nagamine H, Ikeda M, Sakakibara N, Takemura H, Fujii S, Watanabe Y. Therapeutic angiogenesis with intramyocardial administration of basic fibroblast growth factor. Ann Thorac Surg. 2000; 69:1155-1161. [PubMed: 10800811]

94. Iwakura A, Fujita M, Kataoka K, Tambara K, Sakakibara Y, Komeda M, Tabata Y. Intramyocardial sustained delivery of basic fibroblast growth factor improves angiogenesis and ventricular function in a rat infarct model. Heart Vessels. 2003; 18:93-99. [PubMed: 12756606]

95. House SL, Wang J, Castro AM, Weinheimer C, Kovacs A, Ornitz DM. Fibroblast growth factor 2 is an essential cardioprotective factor in a closed-chest model of cardiac ischemia-reperfusion injury. Physiol Rep. 2015; 3

96. Meng X, Brown JM, Ao L, Shames BD, Banerjee A, Harken AH. Reduction of infarct size in the rat heart by LPS preconditioning is associated with expression of angiogenic growth factors and increased capillary density. Shock. 1999; 12:25-31. [PubMed: 10468048]

97. Scheinowitz M, Kotlyar A, Zimand S, Ohad D, Leibovitz I, Bloom N, Goldberg I, Nass D, Engelberg S, Savion N, et al. Basic fibroblast growth factor induces myocardial hypertrophy following acute infarction in rats. Exp Physiol. 1998; 83:585-593. [PubMed: 9793779]

98. Jiang ZS, Jeyaraman M, Wen GB, Fandrich RR, Dixon IM, Cattini PA, Kardami E. High- but not low-molecular weight FGF-2 causes cardiac hypertrophy in vivo; possible involvement of cardiotrophin-1. J Mol Cell Cardiol. 2007; 42:222-233. [PubMed: 17045289]

99. Rosenblatt-Velin N, Lepore MG, Cartoni C, Beermann F, Pedrazzini T. FGF-2 controls the differentiation of resident cardiac precursors into functional cardiomyocytes. J Clin Invest. 2005; 115:1724-1733. [PubMed: 15951838]

100. Yanagisawa-Miwa A, Uchida Y, Nakamura F, Tomaru T, Kido H, Kamijo T, Sugimoto T, Kaji K, Utsuyama M, Kurashima C, et al. Salvage of infarcted myocardium by angiogenic action of basic fibroblast growth factor. Science. 1992; 257:1401-1403. [PubMed: 1382313]

101. Unger EF, Banai S, Shou M, Lazarous DF, Jaklitsch MT, Scheinowitz M, Correa R, Klingbeil C, Epstein SE. Basic fibroblast growth factor enhances myocardial collateral flow in a canine model. Am J Physiol. 1994; 266:H1588-1595. [PubMed: 8184938]

102. Casscells W, Speir E, Sasse J, Klagsbrun M, Allen P, Lee M, Calvo B, Chiba M, Haggroth L, Folkman J, et al. Isolation, characterization, and localization of heparin-binding growth factors in the heart. J Clin Invest. 1990; 85:433-441. [PubMed: 2298919]

103. Speir E, Zhou YF, Lee M, Shrivastav S, Casscells W. Fibroblast growth factors are present in adult cardiac myocytes, in vivo [corrected and issued with original paging in Biochem Biophys Res Commun 1988 Dec 30;157(3)]. Biochem Biophys Res Commun. 1989; 159:1336-1340. [PubMed: 2719673]

104. Kardami E, Fandrich RR. Basic fibroblast growth factor in atria and ventricles of the vertebrate heart. J Cell Biol. 1989; 109:1865-1875. [PubMed: 2677031]

105. Iwakura A, Fujita M, Ikemoto M, Hasegawa K, Nohara R, Sasayama S, Miyamoto S, Yamazato A, Tambara K, Komeda M. Myocardial ischemia enhances the expression of acidic fibroblast growth factor in human pericardial fluid. Heart Vessels. 2000; 15:112-116. [PubMed: 11289498]

106. Suzuki G, Lee TC, Fallavollita JA, Canty JM Jr. Adenoviral gene transfer of FGF-5 to hibernating myocardium improves function and stimulates myocytes to hypertrophy and reenter the cell cycle. Circ Res. 2005; 96:767-775. [PubMed: 15761196]

107. Korf-Klingebiel M, Kempf T, Schluter KD, Willenbockel C, Brod T, Heineke J, Schmidt VJ, Jantzen F, Brandes RP, Sugden PH, et al. Conditional transgenic expression of fibroblast growth factor 9 in the adult mouse heart reduces heart failure mortality after myocardial infarction. Circulation. 2011; 123:504-514. [PubMed: 21262993]

108. Miyamoto M, Naruo K, Seko C, Matsumoto S, Kondo T, Kurokawa T. Molecular cloning of a novel cytokine cDNA encoding the ninth member of the fibroblast growth factor family, which has a unique secretion property. Mol Cell Biol. 1993; 13:4251-4259. [PubMed: 8321227]

109. Wang J, Sontag D, Cattini PA. Heart-specific expression of FGF-16 and a potential role in postnatal cardioprotection. Cytokine Growth Factor Rev. 2015; 26:59-66. [PubMed: 25106133] 
110. Sontag DP, Wang J, Kardami E, Cattini PA. FGF-2 and FGF-16 protect isolated perfused mouse hearts from acute doxorubicin-induced contractile dysfunction. Cardiovasc Toxicol. 2013; 13:244-253. [PubMed: 23430353]

111. Matsumoto E, Sasaki S, Kinoshita H, Kito T, Ohta H, Konishi M, Kuwahara K, Nakao K, Itoh N. Angiotensin II-induced cardiac hypertrophy and fibrosis are promoted in mice lacking Fgf16. Genes Cells. 2013; 18:544-553. [PubMed: 23600527]

112. Lavine KJ, Ornitz DM. Fibroblast growth factors and Hedgehogs: at the heart of the epicardial signaling center. Trends Genet. 2008; 24:33-40. [PubMed: 18054407]

113. Angelin B, Larsson TE, Rudling M. Circulating fibroblast growth factors as metabolic regulators--a critical appraisal. Cell Metab. 2012; 16:693-705. [PubMed: 23217254]

114. Kharitonenkov A. FGFs and metabolism. Curr Opin Pharmacol. 2009; 9:805-810. [PubMed: 19683963]

115. Ito S, Kinoshita S, Shiraishi N, Nakagawa S, Sekine S, Fujimori T, Nabeshima YI. Molecular cloning and expression analyses of mouse betaklotho, which encodes a novel Klotho family protein. Mech Dev. 2000; 98:115-119. [PubMed: 11044614]

116. Kuro-o M. Klotho and betaKlotho. Adv Exp Med Biol. 2012; 728:25-40. [PubMed: 22396160]

117. Owen BM, Mangelsdorf DJ, Kliewer SA. Tissue-specific actions of the metabolic hormones FGF15/19 and FGF21. Trends Endocrinol Metab. 2015; 26:22-29. [PubMed: 25476453]

118. Inagaki T, Choi M, Moschetta A, Peng L, Cummins CL, McDonald JG, Luo G, Jones SA, Goodwin B, Richardson JA, et al. Fibroblast growth factor 15 functions as an enterohepatic signal to regulate bile acid homeostasis. Cell Metab. 2005; 2:217-225. [PubMed: 16213224]

119. Holt JA, Luo G, Billin AN, Bisi J, McNeill YY, Kozarsky KF, Donahee M, Wang DY, Mansfield TA, Kliewer SA, et al. Definition of a novel growth factor-dependent signal cascade for the suppression of bile acid biosynthesis. Genes Dev. 2003; 17:1581-1591. [PubMed: 12815072]

120. Shin DJ, Osborne TF. FGF15/FGFR4 integrates growth factor signaling with hepatic bile acid metabolism and insulin action. J Biol Chem. 2009; 284:11110-11120. [PubMed: 19237543]

121. Nicholes K, Guillet S, Tomlinson E, Hillan K, Wright B, Frantz GD, Pham TA, Dillard-Telm L, Tsai SP, Stephan JP, et al. A mouse model of hepatocellular carcinoma: ectopic expression of fibroblast growth factor 19 in skeletal muscle of transgenic mice. Am J Pathol. 2002; 160:22952307. [PubMed: 12057932]

122. Wu X, Ge H, Lemon B, Vonderfecht S, Weiszmann J, Hecht R, Gupte J, Hager T, Wang Z, Lindberg R, et al. FGF19-induced hepatocyte proliferation is mediated through FGFR4 activation. J Biol Chem. 2010; 285:5165-5170. [PubMed: 20018895]

123. Markan KR, Naber MC, Ameka MK, Anderegg MD, Mangelsdorf DJ, Kliewer SA, Mohammadi M, Potthoff MJ. Circulating FGF21 is liver derived and enhances glucose uptake during refeeding and overfeeding. Diabetes. 2014; 63:4057-4063. [PubMed: 25008183]

124. Ding X, Boney-Montoya J, Owen BM, Bookout AL, Coate KC, Mangelsdorf DJ, Kliewer SA. betaKlotho is required for fibroblast growth factor 21 effects on growth and metabolism. Cell Metab. 2012; 16:387-393. [PubMed: 22958921]

125. Adams AC, Cheng CC, Coskun T, Kharitonenkov A. FGF21 requires betaklotho to act in vivo. PLoS One. 2012; 7:e49977. [PubMed: 23209629]

126. Adams AC, Yang C, Coskun T, Cheng CC, Gimeno RE, Luo Y, Kharitonenkov A. The breadth of FGF21's metabolic actions are governed by FGFR1 in adipose tissue. Mol Metab. 2012; 2:31-37. [PubMed: 24024127]

127. Foltz IN, Hu S, King C, Wu X, Yang C, Wang W, Weiszmann J, Stevens J, Chen JS, Nuanmanee $\mathrm{N}$, et al. Treating diabetes and obesity with an FGF21-mimetic antibody activating the betaKlotho/FGFR1c receptor complex. Sci Transl Med. 2012; 4:162ra153.

128. Fisher FM, Kleiner S, Douris N, Fox EC, Mepani RJ, Verdeguer F, Wu J, Kharitonenkov A, Flier JS, Maratos-Flier E, et al. FGF21 regulates PGC-1alpha and browning of white adipose tissues in adaptive thermogenesis. Genes Dev. 2012; 26:271-281. [PubMed: 22302939]

129. Xu J, Lloyd DJ, Hale C, Stanislaus S, Chen M, Sivits G, Vonderfecht S, Hecht R, Li YS, Lindberg RA, et al. Fibroblast growth factor 21 reverses hepatic steatosis, increases energy expenditure, and improves insulin sensitivity in diet-induced obese mice. Diabetes. 2009; 58:250-259. [PubMed: 18840786] 
130. Coskun T, Bina HA, Schneider MA, Dunbar JD, Hu CC, Chen Y, Moller DE, Kharitonenkov A. Fibroblast growth factor 21 corrects obesity in mice. Endocrinology. 2008; 149:6018-6027. [PubMed: 18687777]

131. Potthoff MJ, Inagaki T, Satapati S, Ding X, He T, Goetz R, Mohammadi M, Finck BN, Mangelsdorf DJ, Kliewer SA, et al. FGF21 induces PGC-1alpha and regulates carbohydrate and fatty acid metabolism during the adaptive starvation response. Proc Natl Acad Sci U S A. 2009; 106:10853-10858. [PubMed: 19541642]

132. Kan M, Wu X, Wang F, McKeehan WL. Specificity for fibroblast growth factors determined by heparan sulfate in a binary complex with the receptor kinase. J Biol Chem. 1999; 274:1594715952. [PubMed: 10336501]

133. Lin BC, Wang M, Blackmore C, Desnoyers LR. Liver-specific activities of FGF19 require Klotho beta. J Biol Chem. 2007; 282:27277-27284. [PubMed: 17627937]

134. An SY, Lee MS, Yi SA, Ha ES, Han SJ, Kim HJ, Kim DJ, Lee KW. Serum fibroblast growth factor 21 was elevated in subjects with type 2 diabetes mellitus and was associated with the presence of carotid artery plaques. Diabetes Res Clin Pract. 2012; 96:196-203. [PubMed: 22293928]

135. Mraz M, Bartlova M, Lacinova Z, Michalsky D, Kasalicky M, Haluzikova D, Matoulek M, Dostalova I, Humenanska V, Haluzik M. Serum concentrations and tissue expression of a novel endocrine regulator fibroblast growth factor- 21 in patients with type 2 diabetes and obesity. Clin Endocrinol (Oxf). 2009; 71:369-375. [PubMed: 19702724]

136. Chavez AO, Molina-Carrion M, Abdul-Ghani MA, Folli F, Defronzo RA, Tripathy D. Circulating fibroblast growth factor-21 is elevated in impaired glucose tolerance and type 2 diabetes and correlates with muscle and hepatic insulin resistance. Diabetes Care. 2009; 32:1542-1546. [PubMed: 19487637]

137. Zhang X, Yeung DC, Karpisek M, Stejskal D, Zhou ZG, Liu F, Wong RL, Chow WS, Tso AW, Lam KS, et al. Serum FGF21 levels are increased in obesity and are independently associated with the metabolic syndrome in humans. Diabetes. 2008; 57:1246-1253. [PubMed: 18252893]

138. Badman MK, Kennedy AR, Adams AC, Pissios P, Maratos-Flier E. A very low carbohydrate ketogenic diet improves glucose tolerance in ob/ob mice independently of weight loss. Am J Physiol Endocrinol Metab. 2009; 297:E1197-1204. [PubMed: 19738035]

139. Hale C, Chen MM, Stanislaus S, Chinookoswong N, Hager T, Wang M, Veniant MM, Xu J. Lack of overt FGF21 resistance in two mouse models of obesity and insulin resistance. Endocrinology. 2012; 153:69-80. [PubMed: 22067317]

140. Chartoumpekis DV, Ziros PG, Psyrogiannis AI, Papavassiliou AG, Kyriazopoulou VE, Sykiotis GP, Habeos IG. Nrf2 represses FGF21 during long-term high-fat diet-induced obesity in mice. Diabetes. 2011; 60:2465-2473. [PubMed: 21852674]

141. Fisher FM, Chui PC, Antonellis PJ, Bina HA, Kharitonenkov A, Flier JS, Maratos-Flier E. Obesity is a fibroblast growth factor 21 (FGF21)-resistant state. Diabetes. 2010; 59:2781-2789. [PubMed: 20682689]

142. Liu JJ, Foo JP, Liu S, Lim SC. The role of fibroblast growth factor 21 in diabetes and its complications: A review from clinical perspective. Diabetes Res Clin Pract. 2015

143. Liu S, Quarles LD. How fibroblast growth factor 23 works. J Am Soc Nephrol. 2007; 18:16371647. [PubMed: 17494882]

144. Liu S, Vierthaler L, Tang W, Zhou J, Quarles LD. FGFR3 and FGFR4 do not mediate renal effects of FGF23. J Am Soc Nephrol. 2008; 19:2342-2350. [PubMed: 18753255]

145. Gattineni J, Bates C, Twombley K, Dwarakanath V, Robinson ML, Goetz R, Mohammadi M, Baum M. FGF23 decreases renal NaPi-2a and NaPi-2c expression and induces hypophosphatemia in vivo predominantly via FGF receptor 1. Am J Physiol Renal Physiol. 2009; 297:F282-291. [PubMed: 19515808]

146. Li H, Martin A, David V, Quarles LD. Compound deletion of Fgfr3 and Fgfr4 partially rescues the Hyp mouse phenotype. Am J Physiol Endocrinol Metab. 2011; 300:E508-517. [PubMed: 21139072] 
147. Gattineni J, Twombley K, Goetz R, Mohammadi M, Baum M. Regulation of serum 1,25(OH)2 vitamin D3 levels by fibroblast growth factor 23 is mediated by FGF receptors 3 and 4 . Am $\mathrm{J}$ Physiol Renal Physiol. 2011; 301:F371-377. [PubMed: 21561999]

148. Gattineni J, Alphonse P, Zhang Q, Mathews N, Bates CM, Baum M. Regulation of renal phosphate transport by FGF23 is mediated by FGFR1 and FGFR4. Am J Physiol Renal Physiol. 2014; 306:F351-358. [PubMed: 24259513]

149. Olauson H, Lindberg K, Amin R, Jia T, Wernerson A, Andersson G, Larsson TE. Targeted deletion of Klotho in kidney distal tubule disrupts mineral metabolism. J Am Soc Nephrol. 2012; 23:1641-1651. [PubMed: 22878961]

150. Lindberg K, Amin R, Moe OW, Hu MC, Erben RG, Ostman Wernerson A, Lanske B, Olauson H, Larsson TE. The kidney is the principal organ mediating klotho effects. J Am Soc Nephrol. 2014; 25:2169-2175. [PubMed: 24854271]

151. Saito H, Maeda A, Ohtomo S, Hirata M, Kusano K, Kato S, Ogata E, Segawa H, Miyamoto K, Fukushima N. Circulating FGF-23 is regulated by 1alpha, 25-dihydroxyvitamin D3 and phosphorus in vivo. J Biol Chem. 2005; 280:2543-2549. [PubMed: 15531762]

152. Shimada T, Hasegawa H, Yamazaki Y, Muto T, Hino R, Takeuchi Y, Fujita T, Nakahara K, Fukumoto S, Yamashita T. FGF-23 is a potent regulator of vitamin D metabolism and phosphate homeostasis. J Bone Miner Res. 2004; 19:429-435. [PubMed: 15040831]

153. Liu S, Gupta A, Quarles LD. Emerging role of fibroblast growth factor 23 in a bone-kidney axis regulating systemic phosphate homeostasis and extracellular matrix mineralization. Curr Opin Nephrol Hypertens. 2007; 16:329-335. [PubMed: 17565275]

154. Quarles LD. FGF23, PHEX, and MEPE regulation of phosphate homeostasis and skeletal mineralization. Am J Physiol Endocrinol Metab. 2003; 285:E1-9. [PubMed: 12791601]

155. Liu S, Tang W, Zhou J, Stubbs JR, Luo Q, Pi M, Quarles LD. Fibroblast growth factor 23 is a counter-regulatory phosphaturic hormone for vitamin D. J Am Soc Nephrol. 2006; 17:13051315. [PubMed: 16597685]

156. Planavila A, Redondo I, Hondares E, Vinciguerra M, Munts C, Iglesias R, Gabrielli LA, Sitges M, Giralt M, van Bilsen M, et al. Fibroblast growth factor 21 protects against cardiac hypertrophy in mice. Nat Commun. 2013; 4:2019. [PubMed: 23771152]

157. Liu SQ, Roberts D, Kharitonenkov A, Zhang B, Hanson SM, Li YC, Zhang LQ, Wu YH. Endocrine protection of ischemic myocardium by FGF21 from the liver and adipose tissue. Sci Rep. 2013; 3:2767. [PubMed: 24067542]

158. Joki Y, Ohashi K, Yuasa D, Shibata R, Ito M, Matsuo K, Kambara T, Uemura Y., Hayakawa S. Hiramatsu-Ito M, et al. FGF21 attenuates pathological myocardial remodeling following myocardial infarction through the adiponectin-dependent mechanism. Biochem Biophys Res Commun. 2015; 459:124-130. [PubMed: 25712519]

159. Planavila A, Redondo-Angulo I, Ribas F, Garrabou G, Casademont J, Giralt M, Villarroya F. Fibroblast growth factor 21 protects the heart from oxidative stress. Cardiovasc Res. 2015; 106:19-31. [PubMed: 25538153]

160. Patel V, Adya R, Chen J, Ramanjaneya M, Bari MF, Bhudia SK, Hillhouse EW, Tan BK, Randeva HS. Novel insights into the cardio-protective effects of FGF21 in lean and obese rat hearts. PLoS One. 2014; 9:e87102. [PubMed: 24498293]

161. Tanajak P, Sa-Nguanmoo P, Wang X, Liang G, Li X, Jiang C, Chattipakorn SC, Chattipakorn N. Fibroblast growth factor 21 (FGF21) therapy attenuates left ventricular dysfunction and metabolic disturbance by improving FGF21 sensitivity, cardiac mitochondrial redox homoeostasis and structural changes in pre-diabetic rats. Acta Physiol (Oxf). 2016; 217:287-299. [PubMed: 27119620]

162. Yan X, Chen J, Zhang C, Zhou S, Zhang Z, Chen J, Feng W, Li X, Tan Y. FGF21 deletion exacerbates diabetic cardiomyopathy by aggravating cardiac lipid accumulation. J Cell Mol Med. 2015; 19:1557-1568. [PubMed: 25823710]

163. Brahma MK, Adam RC, Pollak NM, Jaeger D, Zierler KA, Pocher N, Schreiber R, Romauch M, Moustafa T, Eder S, et al. Fibroblast growth factor 21 is induced upon cardiac stress and alters cardiac lipid homeostasis. J Lipid Res. 2014; 55:2229-2241. [PubMed: 25176985] 
164. Zhang C, Huang Z, Gu J, Yan X, Lu X, Zhou S, Wang S, Shao M, Zhang F, Cheng P, et al. Fibroblast growth factor 21 protects the heart from apoptosis in a diabetic mouse model via extracellular signal-regulated kinase 1/2-dependent signalling pathway. Diabetologia. 2015; 58:1937-1948. [PubMed: 26040473]

165. Semba RD, Crasto C, Strait J, Sun K, Schaumberg DA, Ferrucci L. Elevated serum fibroblast growth factor 21 is associated with hypertension in community-dwelling adults. J Hum Hypertens. 2013; 27:397-399. [PubMed: 23190795]

166. Shen Y, Ma X, Zhou J, Pan X, Hao Y, Zhou M, Lu Z, Gao M, Bao Y, Jia W. Additive relationship between serum fibroblast growth factor 21 level and coronary artery disease. Cardiovasc Diabetol. 2013; 12:124. [PubMed: 23981342]

167. Lin Z, Wu Z, Yin X, Liu Y, Yan X, Lin S, Xiao J, Wang X, Feng W, Li X. Serum levels of FGF-21 are increased in coronary heart disease patients and are independently associated with adverse lipid profile. PLoS One. 2010; 5:e15534. [PubMed: 21206918]

168. Zhang W, Chu S, Ding W, Wang F. Serum Level of Fibroblast Growth Factor 21 Is Independently Associated with Acute Myocardial Infarction. PLoS One. 2015; 10:e0129791. [PubMed: 26091256]

169. Han X, Chen C, Cheng G, Xie C, Yang M, Shou X, Sun C. Serum fibroblast growth factor 21 levels are increased in atrial fibrillation patients. Cytokine. 2015; 73:176-180. [PubMed: 25766411]

170. Wang R, Yi X, Li X, Jiang X. Fibroblast growth factor-21 is positively associated with atrial fibrosis in atrial fibrillation patients with rheumatic heart disease. Int J Clin Exp Pathol. 2015; 8:14901-14908. [PubMed: 26823820]

171. Chou RH, Huang PH, Hsu CY, Chang CC, Leu HB, Huang CC, Chen JW, Lin SJ. Circulating Fibroblast Growth Factor 21 is Associated with Diastolic Dysfunction in Heart Failure Patients with Preserved Ejection Fraction. Sci Rep. 2016; 6:33953. [PubMed: 27650781]

172. Lenart-Lipinska M, Matyjaszek-Matuszek B, Gernand W, Nowakowski A, Solski J. Serum fibroblast growth factor 21 is predictive of combined cardiovascular morbidity and mortality in patients with type 2 diabetes at a relatively short-term follow-up. Diabetes Res Clin Pract. 2013; 101:194-200. [PubMed: 23768789]

173. Ong KL, Januszewski AS, O'Connell R, Jenkins AJ, Xu A, Sullivan DR, Barter PJ, Hung WT, Scott RS, Taskinen MR, et al. The relationship of fibroblast growth factor 21 with cardiovascular outcome events in the Fenofibrate Intervention and Event Lowering in Diabetes study. Diabetologia. 2015; 58:464-473. [PubMed: 25425220]

174. Zhang J, Cheng Y, Gu J, Wang S, Zhou S, Wang Y, Tan Y, Feng W, Fu Y, Mellen N, et al. Fenofibrate increases cardiac autophagy via FGF21/SIRT1 and prevents fibrosis and inflammation in the hearts of Type 1 diabetic mice. Clin Sci (Lond). 2016; 130:625-641. [PubMed: 26795437]

175. Touchberry CD, Green TM, Tchikrizov V, Mannix JE, Mao TF, Carney BW, Girgis M, Vincent RJ, Wetmore LA, Dawn B, et al. FGF23 is a novel regulator of intracellular calcium and cardiac contractility in addition to cardiac hypertrophy. Am J Physiol Endocrinol Metab. 2013; 304:E863-873. [PubMed: 23443925]

176. Faul C, Amaral AP, Oskouei B, Hu MC, Sloan A, Isakova T, Gutierrez OM, Aguillon-Prada R, Lincoln J, Hare JM, et al. FGF23 induces left ventricular hypertrophy. J Clin Invest. 2011; 121:4393-4408. [PubMed: 21985788]

177. Hu MC, Shi M, Cho HJ, Adams-Huet B, Paek J, Hill K, Shelton J, Amaral AP, Faul C, Taniguchi $\mathrm{M}$, et al. Klotho and phosphate are modulators of pathologic uremic cardiac remodeling. J Am Soc Nephrol. 2014

178. Shobeiri N, Pang J, Adams MA, Holden RM. Cardiovascular disease in an adenine-induced model of chronic kidney disease: the temporal link between vascular calcification and haemodynamic consequences. J Hypertens. 2013; 31:160-168. [PubMed: 23183279]

179. Faul C. Fibroblast growth factor 23 and the heart. Curr Opin Nephrol Hypertens. 2012; 21:369375. [PubMed: 22531163] 
180. Yu X, Ibrahimi OA, Goetz R, Zhang F, Davis SI, Garringer HJ, Linhardt RJ, Ornitz DM, Mohammadi M, White KE. Analysis of the biochemical mechanisms for the endocrine actions of fibroblast growth factor-23. Endocrinology. 2005; 146:4647-4656. [PubMed: 16081635]

181. Goetz R, Ohnishi M, Kir S, Kurosu H, Wang L, Pastor J, Ma J, Gai W, Kuro-o M, Razzaque MS, et al. Conversion of a paracrine fibroblast growth factor into an endocrine fibroblast growth factor. J Biol Chem. 2012; 287:29134-29146. [PubMed: 22733815]

182. Coresh J, Selvin E, Stevens LA, Manzi J, Kusek JW, Eggers P, Van Lente F, Levey AS. Prevalence of chronic kidney disease in the United States. JAMA. 2007; 298:2038-2047. [PubMed: 17986697]

183. Go AS, Chertow GM, Fan D, McCulloch CE, Hsu CY. Chronic kidney disease and the risks of death, cardiovascular events, and hospitalization. N Engl J Med. 2004; 351:1296-1305. [PubMed: 15385656]

184. Lowrie EG, Huang WH, Lew NL. Death risk predictors among peritoneal dialysis and hemodialysis patients: a preliminary comparison. Am J Kidney Dis. 1995; 26:220-228. [PubMed: 7611256]

185. Zager PG, Nikolic J, Brown RH, Campbell MA, Hunt WC, Peterson D, Van Stone J, Levey A, Meyer KB, Klag MJ, et al. "U" curve association of blood pressure and mortality in hemodialysis patients. Medical Directors of Dialysis Clinic, Inc. Kidney Int. 1998; 54:561-569. [PubMed: 9690224]

186. Gross ML, Ritz E. Hypertrophy and fibrosis in the cardiomyopathy of uremia--beyond coronary heart disease. Semin Dial. 2008; 21:308-318. [PubMed: 18627569]

187. Rambausek M, Ritz E, Mall G, Mehls O, Katus H. Myocardial hypertrophy in rats with renal insufficiency. Kidney Int. 1985; 28:775-782. [PubMed: 2935673]

188. Siedlecki AM, Jin X, Muslin AJ. Uremic cardiac hypertrophy is reversed by rapamycin but not by lowering of blood pressure. Kidney Int. 2009; 75:800-808. [PubMed: 19165175]

189. Ritz E. Left ventricular hypertrophy in renal disease: beyond preload and afterload. Kidney Int. 2009; 75:771-773. [PubMed: 19337217]

190. Gutierrez OM, Januzzi JL, Isakova T, Laliberte K, Smith K, Collerone G, Sarwar A, Hoffmann U, Coglianese E, Christenson R, et al. Fibroblast growth factor 23 and left ventricular hypertrophy in chronic kidney disease. Circulation. 2009; 119:2545-2552. [PubMed: 19414634]

191. Seiler S, Reichart B, Roth D, Seibert E, Fliser D, Heine GH. FGF-23 and future cardiovascular events in patients with chronic kidney disease before initiation of dialysis treatment. Nephrol Dial Transplant. 2010; 25:3983-3989. [PubMed: 20525642]

192. Gutierrez OM, Mannstadt M, Isakova T, Rauh-Hain JA, Tamez H, Shah A, Smith K, Lee H, Thadhani R, Juppner H, et al. Fibroblast growth factor 23 and mortality among patients undergoing hemodialysis. N Engl J Med. 2008; 359:584-592. [PubMed: 18687639]

193. Isakova T, Xie H, Yang W, Xie D, Anderson AH, Scialla J, Wahl P, Gutierrez OM, Steigerwalt S, $\mathrm{He} \mathrm{J}$, et al. Fibroblast growth factor 23 and risks of mortality and end-stage renal disease in patients with chronic kidney disease. JAMA. 2011; 305:2432-2439. [PubMed: 21673295]

194. Kendrick J, Cheung AK, Kaufman JS, Greene T, Roberts WL, Smits G, Chonchol M. FGF-23 associates with death, cardiovascular events, and initiation of chronic dialysis. J Am Soc Nephrol. 2010; 22:1913-1922.

195. Hsu HJ, Wu MS. Fibroblast growth factor 23: a possible cause of left ventricular hypertrophy in hemodialysis patients. Am J Med Sci. 2009; 337:116-122. [PubMed: 19214027]

196. Kirkpantur A, Balci M, Gurbuz OA, Afsar B, Canbakan B, Akdemir R, Ayli MD. Serum fibroblast growth factor-23 (FGF-23) levels are independently associated with left ventricular mass and myocardial performance index in maintenance haemodialysis patients. Nephrol Dial Transplant. 2011; 26:1346-1354. [PubMed: 20813767]

197. Seeherunvong W, Abitbol CL, Chandar J, Rusconi P, Zilleruelo GE, Freundlich M. Fibroblast growth factor 23 and left ventricular hypertrophy in children on dialysis. Pediatr Nephrol. 2012; 27:2129-2136. [PubMed: 22710695]

198. Di Marco GS, Reuter S, Kentrup D, Grabner A, Amaral AP, Fobker M, Stypmann J, Pavenstadt $\mathrm{H}$, Wolf M, Faul C, et al. Treatment of established left ventricular hypertrophy with fibroblast 
growth factor receptor blockade in an animal model of CKD. Nephrol Dial Transplant. 2014; 29:2028-2035. [PubMed: 24875663]

199. Block GA, Wheeler DC, Persky MS, Kestenbaum B, Ketteler M, Spiegel DM, Allison MA, Asplin J, Smits G, Hoofnagle AN, et al. Effects of phosphate binders in moderate CKD. J Am Soc Nephrol. 2012; 23:1407-1415. [PubMed: 22822075]

200. Shalhoub V, Shatzen EM, Ward SC, Davis J, Stevens J, Bi V, Renshaw L, Hawkins N, Wang W, Chen C, et al. FGF23 neutralization improves chronic kidney disease-associated hyperparathyroidism yet increases mortality. J Clin Invest. 2012; 122:2543-2553. [PubMed: 22728934]

201. Weinstein M, Xu X, Ohyama K, Deng CX. FGFR-3 and FGFR-4 function cooperatively to direct alveogenesis in the murine lung. Development. 1998; 125:3615-3623. [PubMed: 9716527]

202. Srisuma S, Bhattacharya S, Simon DM, Solleti SK, Tyagi S, Starcher B, Mariani TJ. Fibroblast growth factor receptors control epithelial-mesenchymal interactions necessary for alveolar elastogenesis. Am J Respir Crit Care Med. 2010; 181:838-850. [PubMed: 20093646]

203. Rossaint J, Oehmichen J, Van Aken H, Reuter S, Pavenstadt HJ, Meersch M, Unruh M, Zarbock A. FGF23 signaling impairs neutrophil recruitment and host defense during CKD. J Clin Invest. 2016; 126:962-974. [PubMed: 26878171]

204. Singh S, Grabner A, Yanucil C, Schramm K, Czaya B, Krick S, Czaja MJ, Bartz R, Abraham R, Di Marco GS, et al. Fibroblast growth factor 23 directly targets hepatocytes to promote inflammation in chronic kidney disease. Kidney Int. 2016

205. Dai B, David V, Martin A, Huang J, Li H, Jiao Y, Gu W, Quarles LD. A comparative transcriptome analysis identifying FGF23 regulated genes in the kidney of a mouse CKD model. PLoS One. 2012; 7:e44161. [PubMed: 22970174]

206. Masuda Y, Ohta H, Morita Y, Nakayama Y, Miyake A, Itoh N, Konishi M. Expression of Fgf23 in activated dendritic cells and macrophages in response to immunological stimuli in mice. Biol Pharm Bull. 2015; 38:687-693. [PubMed: 25739891]

207. Han X, Li L, Yang J, King G, Xiao Z, Quarles LD. Counter-regulatory paracrine actions of FGF-23 and 1,25(OH)2 D in macrophages. FEBS Lett. 2016; 590:53-67. [PubMed: 26762170]

208. Yamauchi M, Hirohashi Y, Torigoe T, Matsumoto Y, Yamashita K, Kayama M, Sato N, Yotsuyanagi T. Wound healing delays in alpha-Klotho-deficient mice that have skin appearance similar to that in aged humans - Study of delayed wound healing mechanism. Biochem Biophys Res Commun. 2016

209. Ritter C, Zhang S, Finch JL, Liapis H, Suarez E, Ferder L, Delmez J, Slatopolsky E. Cardiac and renal effects of atrasentan in combination with enalapril and paricalcitol in uremic rats. Kidney Blood Press Res. 2014; 39:340-352. [PubMed: 25300759]

210. Maizel J, Six I, Dupont S, Secq E, Dehedin B, Barreto FC, Benchitrit J, Poirot S, Slama M, Tribouilloy $\mathrm{C}$, et al. Effects of sevelamer treatment on cardiovascular abnormalities in mice with chronic renal failure. Kidney Int. 2013; 84:491-500. [PubMed: 23594676]

211. Tian J, Shidyak A, Periyasamy SM, Haller S, Taleb M, El-Okdi N, Elkareh J, Gupta S, Gohara S, Fedorova OV, et al. Spironolactone attenuates experimental uremic cardiomyopathy by antagonizing marinobufagenin. Hypertension. 2009; 54:1313-1320. [PubMed: 19884563]

212. Lekawanvijit S, Kompa AR, Wang BH, Kelly DJ, Krum H. Cardiorenal syndrome: the emerging role of protein-bound uremic toxins. Circ Res. 2012; 111:1470-1483. [PubMed: 23139286]

213. Andrukhova O, Slavic S, Smorodchenko A, Zeitz U, Shalhoub V, Lanske B, Pohl EE, Erben RG. FGF23 regulates renal sodium handling and blood pressure. EMBO Mol Med. 2014; 6:744-759. [PubMed: 24797667]

214. Seiler S, Cremers B, Rebling NM, Hornof F, Jeken J, Kersting S, Steimle C, Ege P, Fehrenz M, Rogacev KS, et al. The phosphatonin fibroblast growth factor 23 links calcium-phosphate metabolism with left-ventricular dysfunction and atrial fibrillation. Eur Heart J. 2011; 32:26882696. [PubMed: 21733911]

215. Isakova T, Houston J, Santacruz L, Schiavenato E, Somarriba G, Harmon WG, Lipshultz SE, Miller TL, Rusconi PG. Associations between fibroblast growth factor 23 and cardiac characteristics in pediatric heart failure. Pediatr Nephrol. 2013; 28:2035-2042. [PubMed: 23740037] 
216. Shibata K, Fujita S, Morita H, Okamoto Y, Sohmiya K, Hoshiga M, Ishizaka N. Association between circulating fibroblast growth factor 23, alpha-Klotho, and the left ventricular ejection fraction and left ventricular mass in cardiology inpatients. PLoS One. 2013; 8:e73184. [PubMed: 24039882]

217. Imazu M, Takahama H, Asanuma H, Funada A, Sugano Y, Ohara T, Hasegawa T, Asakura M, Kanzaki H, Anzai T, et al. Pathophysiological impact of serum fibroblast growth factor 23 in patients with nonischemic cardiac disease and early chronic kidney disease. Am J Physiol Heart Circ Physiol. 2014; 307:H1504-1511. [PubMed: 25217649]

218. Wohlfahrt P, Melenovsky V, Kotrc M, Benes J, Jabor A, Franekova J, Lemaire S, Kautzner J, Jarolim P. Association of Fibroblast Growth Factor-23 Levels and Angiotensin-Converting Enzyme Inhibition in Chronic Systolic Heart Failure. JACC Heart Fail. 2015; 3:829-839. [PubMed: 26450001]

219. Andersen IA, Huntley BK, Sandberg SS, Heublein DM, Burnett JC Jr. Elevation of circulating but not myocardial FGF23 in human acute decompensated heart failure. Nephrol Dial Transplant. 2015

220. Andrukhova O, Slavic S, Odorfer KI, Erben RG. Experimental Myocardial Infarction Upregulates Circulating Fibroblast Growth Factor-23. J Bone Miner Res. 2015; 30:1831-1839. [PubMed: 25858796]

221. Ito N, Wijenayaka AR, Prideaux M, Kogawa M, Ormsby RT, Evdokiou A, Bonewald LF, Findlay DM, Atkins GJ. Regulation of FGF23 expression in IDG-SW3 osteocytes and human bone by pro-inflammatory stimuli. Mol Cell Endocrinol. 2015; 399:208-218. [PubMed: 25458698]

222. David V, Martin A, Isakova T, Spaulding C, Qi L, Ramirez V, Zumbrennen-Bullough KB, Sun $\mathrm{CC}$, Lin HY, Babitt JL, et al. Inflammation and functional iron deficiency regulate fibroblast growth factor 23 production. Kidney Int. 2015

223. Pathak JL, Bakker AD, Luyten FP, Verschueren P, Lems WF, Klein-Nulend J, Bravenboer N. Systemic Inflammation Affects Human Osteocyte-Specific Protein and Cytokine Expression. Calcif Tissue Int. 2016

224. Richter MP, V, Gajawada P, Poeling J, Warnecke h. Braun T, Walther T, Kubin T. Oncostatin M induces FGF23 expression in cardiomyocytes. J Clin Exp Cardiolog. 2012; S:9.

225. Richter M, Lautze HJ, Walther T, Braun T, Kostin S, Kubin T. The failing heart is a major source of circulating FGF23 via oncostatin M receptor activation. J Heart Lung Transplant. 2015; 34:1211-1214. [PubMed: 26267742]

226. Yan L, Mathew L, Chellan B, Gardner B, Earley J, Puri TS, Hofmann Bowman MA. S100/ Calgranulin-mediated inflammation accelerates left ventricular hypertrophy and aortic valve sclerosis in chronic kidney disease in a receptor for advanced glycation end products-dependent manner. Arterioscler Thromb Vasc Biol. 2014; 34:1399-1411. [PubMed: 24855059]

227. Yan L, Bowman MA. Chronic sustained inflammation links to left ventricular hypertrophy and aortic valve sclerosis: a new link between S100/RAGE and FGF23. Inflamm Cell Signal. 2014; 1

228. Go AS, Mozaffarian D, Roger VL, Benjamin EJ, Berry JD, Blaha MJ, Dai S, Ford ES, Fox CS, Franco S, et al. Heart disease and stroke statistics--2014 update: a report from the American Heart Association. Circulation. 2014; 129:e28-e292. [PubMed: 24352519]

229. Liu Y, Liu Y, Liu X, Chen J, Zhang K, Huang F, Wang JF, Tang W, Huang H. Apocynin Attenuates Cardiac Injury in Type 4 Cardiorenal Syndrome via Suppressing Cardiac Fibroblast Growth Factor-2 With Oxidative Stress Inhibition. J Am Heart Assoc. 2015; 4

230. Reiche M, Bachmann A, Lossner U, Bluher M, Stumvoll M, Fasshauer M. Fibroblast growth factor 19 serum levels: relation to renal function and metabolic parameters. Horm Metab Res. 2010; 42:178-181. [PubMed: 20013647]

231. Han SH, Choi SH, Cho BJ, Lee Y, Lim S, Park YJ, Moon MK, Lee HK, Kang SW, Han DS, et al. Serum fibroblast growth factor-21 concentration is associated with residual renal function and insulin resistance in end-stage renal disease patients receiving long-term peritoneal dialysis. Metabolism. 2010; 59:1656-1662. [PubMed: 20423749]

232. Hindricks J, Ebert T, Bachmann A, Kralisch S, Lossner U, Kratzsch J, Stolzenburg JU, Dietel A, Beige J, Anders M, et al. Serum levels of fibroblast growth factor-21 are increased in chronic and acute renal dysfunction. Clin Endocrinol (Oxf). 2014; 80:918-924. [PubMed: 24612017] 
233. Stein S, Bachmann A, Lossner U, Kratzsch J, Bluher M, Stumvoll M, Fasshauer M. Serum levels of the adipokine FGF21 depend on renal function. Diabetes Care. 2009; 32:126-128. [PubMed: 18840768]

234. Crasto C, Semba RD, Sun K, Ferrucci L. Serum fibroblast growth factor 21 is associated with renal function and chronic kidney disease in community-dwelling adults. J Am Geriatr Soc. 2012; 60:792-793. [PubMed: 22494291]

235. Lin Z, Zhou Z, Liu Y, Gong Q, Yan X, Xiao J, Wang X, Lin S, Feng W, Li X. Circulating FGF21 levels are progressively increased from the early to end stages of chronic kidney diseases and are associated with renal function in Chinese. PLoS One. 2011; 6:e18398. [PubMed: 21525989] 


\section{Highlights}

- $\quad$ FGFs functions as paracrine and endocrine modulators of cardiac structure and function.

- $\quad$ FGFs affect cardiac remodeling by activating fibroblasts and inducing angiogenesis.

- $\quad$ FGFs can also directly target cardiac myocytes and induce cardiac hypertrophy.

- $\quad$ By activating FGFR4, FGF23 contributes to uremic cardiomyopathy. 